Article

\title{
Geochemical Assessment of Potential Sources for Nitrate in the Wasia Aquifer, Al Kharj Area, Central Saudi Arabia
}

\author{
Abid Khogali ${ }^{1, *} \mathbb{C}^{\text {, Peter Birkle }}{ }^{2}$, Abdulaziz Al-Shaibani ${ }^{1,3}{ }^{\oplus}$, Martin Keller ${ }^{3,4}{ }^{-}$, \\ Bassam Tawabini ${ }^{1}$ (D) and Mohammad Makkawi ${ }^{1}$ (D) \\ 1 Geosciences Department, College of Petroleum Engineering and Geosciences, King Fahd University of \\ Petroleum \& Minerals, Dhahran 31261, Saudi Arabia; shaibani@kfupm.edu.sa (A.A.-S.); \\ bassamst@kfupm.edu.sa (B.T.); makkawi@kfupm.edu.sa (M.M.) \\ 2 Geology Technology Team, EXPEC Advanced Research Center (EXPEC ARC), Saudi Aramco, \\ Dhahran 31311, Saudi Arabia; peter.birkle@aramco.com \\ 3 Ministry of Environment, Water, and Agriculture, Riyadh 11195, Saudi Arabia; martin.keller@fau.de \\ 4 GeoZentrum Nordbayern, Universität Erlangen, Schlossgarten 5, 91054 Erlangen, Germany \\ * Correspondence: g201605760@kfupm.edu.sa; Tel.: +966-59-4900753
}

Received: 1 April 2020; Accepted: 10 May 2020; Published: 22 May 2020

\begin{abstract}
Nitrate $\left(\mathrm{NO}_{3}{ }^{-}\right)$represents one of the major groundwater constituents with increasing distribution and concentration in the Kingdom of Saudi Arabia. This study aimed to determine potential sources of nitrate in the Early to Late Cretaceous Wasia aquifer system at the Al Kharj area (Central Saudi Arabia) by an integrative approach using groundwater geochemistry, nitrate isotopes $\left({ }^{15} \mathrm{~N}-\mathrm{NO}_{3}\right.$ and $\left.{ }^{18} \mathrm{O}-\mathrm{NO}_{3}\right)$, and tritium $\left({ }^{3} \mathrm{H}\right)$ measurements. The lowest saline groundwater samples (TDS $=1400-2000 \mathrm{mg} / \mathrm{L}$ ) from the peripheral zone were representative for pristine groundwater from the Wasia aquifer with nitrate concentrations below $20 \mathrm{mg} / \mathrm{L}$ and low ${ }^{18} \mathrm{O}-\mathrm{NO}_{3}$ ratios $(8.7-20.6 \%$ o) but enriched ${ }^{15} \mathrm{~N}-\mathrm{NO}_{3}$ values (up to $10.8 \%$ ). In contrast, 11 out of 34 analyzed water samples from irrigation wells and cattle watering wells exceeded the World Health Organization (WHO) drinking water guideline value for nitrate of $50 \mathrm{mg} / \mathrm{L}$ with maximum concentrations of up to $395 \mathrm{mg} / \mathrm{L}$. Nitrate fertilizers and atmospheric deposition are the main sources of nitrate in groundwater in the eastern and northern sections of the study area. The combination of elevated salinities (4940-7330 mg/L), $\mathrm{NO}_{3}(111-395 \mathrm{mg} / \mathrm{L})$, boron $(516-1430 \mu \mathrm{g} / \mathrm{L})$, and enriched ${ }^{18} \mathrm{O}-\mathrm{NO}_{3}(21.7-25.8 \%$ o $)$ ratios with depleted ${ }^{15} \mathrm{~N}-\mathrm{NO}_{3}(5.7-7.6 \%$ o) confirm the local influx of evaporated irrigation water with remnants of dissolved fertilizer into the Wasia groundwater system. There was no evidence for the influx of animal or human wastes from adjacent dairy, poultry, and housing infrastructures. Tritium concentrations below the detection limit of $0.8 \mathrm{TU}$ for most borehole samples implied the absence of recent natural recharge. The estimated annual average $\mathrm{N}$ influx of 3.34 to $6.67 \mathrm{~kg} / \mathrm{ha}$ to the Wasia aquifer requires a combination of atmospheric deposition and anthropogenic sources (mainly nitrate fertilizers) to increase the nitrogen content of the Wasia aquifer.
\end{abstract}

Keywords: Wasia aquifer; nitrate sources; stable isotopes; geochemistry

\section{Introduction}

The increasing enrichment of nitrate $\left(\mathrm{NO}_{3}^{-}\right)$in groundwater by anthropogenic sources represents a worldwide problem for water quality standards [1-3]. Drinking water with elevated nitrate concentrations may cause severe health issues like blue-baby syndrome (methemoglobinemia) [3]. Multiple studies have been carried out regarding the occurrence and source of nitrate in aquifers [4-7]. High levels of nitrate in the subsurface are usually attributed to the use of inorganic fertilizers, 
animal manure, airborne nitrogen, and non-agricultural sources such as lawn fertilizer, septic systems, and domestic animals in residential areas [8,9]. Natural sources, like atmospheric deposition, nitrogen releases from nitrogen-bearing bedrocks, and hydrothermal waters, are also possible sources of nitrogen [10].

Al Kharj city is one of the oldest agricultural regions in Saudi Arabia, as it falls within a graben system that is covered by fertile Quaternary superficial deposits. Below this Quaternary cover, the graben fill hosts the Biyadh aquifer and the overlying Wasia aquifer. The Wasia aquifer is one of the most prolific sources of groundwater in Saudi Arabia that provides freshwater resources for the city of Riyadh [11,12]. In the Al Kharj area, the Wasia aquifer is primarily exploited for agricultural purposes. It is estimated that more than $90 \%$ of the center pivots of the dairy farms and agricultural complexes are used to grow alfalfa.

Several studies have focused on the chemical characteristics of groundwater in the Al Kharj area [13-17]. Most of these studies have detected elevated nitrate concentrations in this area, which were assumed to be linked to agricultural activities. Some of the studied wells are remote from anthropogenic activities, which raises uncertainty about the source of nitrate in this aquifer. None of these studies have clearly assessed the sources and distribution of these elevated nitrate concentrations. Isotope-based approaches were successfully applied to identify the possible origins of nitrate [18,19]. The radioactive isotope tritium $\left({ }^{3} \mathrm{H}\right)$ can be employed to distinguish groundwater recharge during the pre-bomb time from younger water [4,20]. The tritium content in the atmosphere increased dramatically since the start of the subaerial testing of nuclear bombs in 1952. After 1963, the tritium rate in the atmosphere declined due to the fact of its radioactive decay, precipitation, and the termination of atmospheric nuclear testing. Tritium has a half-life of approximately 12.3 years and is usually expressed in tritium units (TU) [20,21]. The approximate residence time of groundwater is reconstructed by correlating the measured tritium concentrations with the atmospheric tritium decay curve since 1952.

In this study, hydrochemical (major, minor, and trace element) and isotopic $\left({ }^{15} \mathrm{~N}-\mathrm{NO}_{3},{ }^{18} \mathrm{O}-\mathrm{NO}_{3}\right)$ analysis on borehole samples from the shallow Wasia aquifer were performed to assess the potential sources and distribution of nitrate in the Al Kharj area. Isotopic fingerprints of tritium $\left({ }^{3} \mathrm{H}\right)$ were used to assess the possibility of recent recharge to the Wasia aquifer in the Al Kharj area. As a novelty to previous hydrogeological and geochemical studies, the combined assessment of hydrochemical data of major ions ( $\left.\mathrm{Na}, \mathrm{Ca}, \mathrm{K}, \mathrm{Mg}, \mathrm{Cl}, \mathrm{HCO}_{3}, \mathrm{SO}_{4}, \mathrm{NO}_{3}\right)$ and minor elements (i.e., $\mathrm{B}$, Fe), stable $\left({ }^{15} \mathrm{~N}-\mathrm{NO}_{3}\right.$, $\left.{ }^{18} \mathrm{O}-\mathrm{NO}_{3}\right)$, and radiogenic isotopes $\left({ }^{3} \mathrm{H}\right)$ allows quantitative characterization of the pristine composition of the Wasia aquifer in the study area and to trace the source and migration of anthropogenic influx from the surface.

\section{Background}

\subsection{Location and Geology}

The study area is located east of Al Kharj city in Central Saudi Arabia, SE of Riyadh city. The area is situated between $24.00^{\circ} \mathrm{N}$ and $24.35^{\circ} \mathrm{N}$ latitude and $47.40^{\circ} \mathrm{E}$ and $48.00^{\circ} \mathrm{E}$ longitude on an altitude of 400 to $480 \mathrm{~m}$ above sea level (Figure 1). Wadi As-Sahba crosses the central part and represents the lowest elevation point in the study area [14]. The study area is dominated by arid climatic conditions with a wide range of temperatures from $48{ }^{\circ} \mathrm{C}$ during summer to $3^{\circ} \mathrm{C}$ in the winter [14]. The evaporation rate reaches an annual level of $2000 \mathrm{~mm}$, while the average annual rainfall is below $100 \mathrm{~mm}$ [22].

From the geological point of view, the Wasia Group represents an important succession within the extensive Cretaceous sequence of the Arabian Platform (Figure 2). In the study area, the clastic part of the Wasia Group consists of sandstone interbedded with shaly beds. The Albian to Turonian Wasia Group is unconformably underlain by the siliciclastic, Barremian Biyadh Formation, and unconformably covered by Santonian to Danian carbonates of the Aruma Group (Figure 2). The carbonates of the Early Eocene Umm Er Radhuma Formation (Figure 1B) unconformably lie above the Aruma Group. On a regional scale, the Wasia Group crops out as an intermittent curve-shaped structure 
between latitudes of $18^{\circ} \mathrm{N}$ and $30^{\circ} \mathrm{N}$, with a length and width of about $1500 \mathrm{~km}$ and $50 \mathrm{~km}$, respectively (Figure 1) [23,24]. Outcrop thickness of the Group within this discontinuous arc varies from approximately $30 \mathrm{~m}$ in the south to almost $90 \mathrm{~m}$ in the north [24,25].

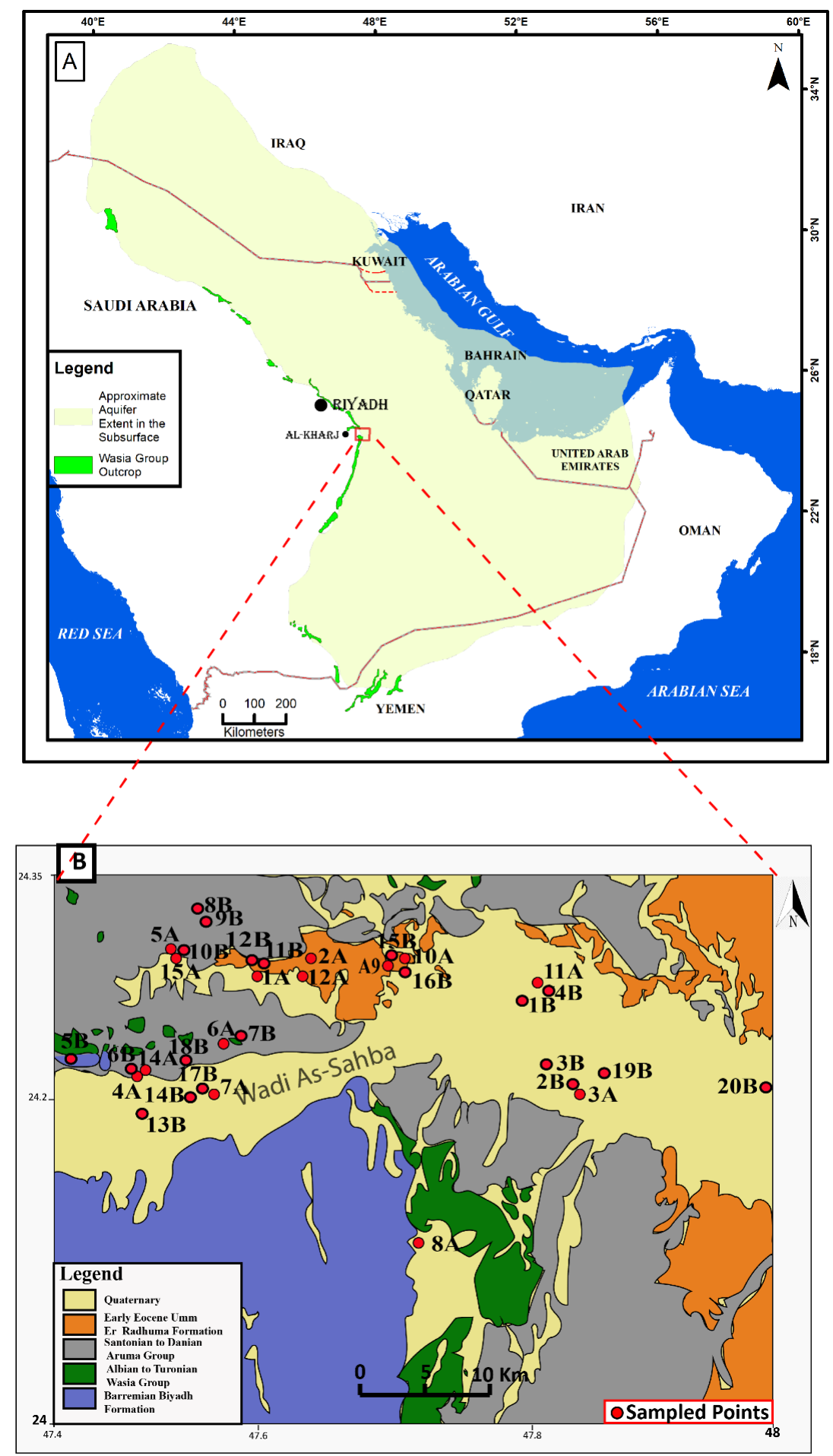

Figure 1. (A) A map of the Arabian Peninsula showing the location of the surface outcrop of the Cretaceous Wasia and the regional extent of the Wasia aquifer in the subsurface (modified from Reference [12,16]). (B) A geological map of the Al Kharj area in Central Saudi Arabia with sampling points of supply water wells from the present study. A wadi is a valley, ravine, or channel that is dry except in rainy season. 


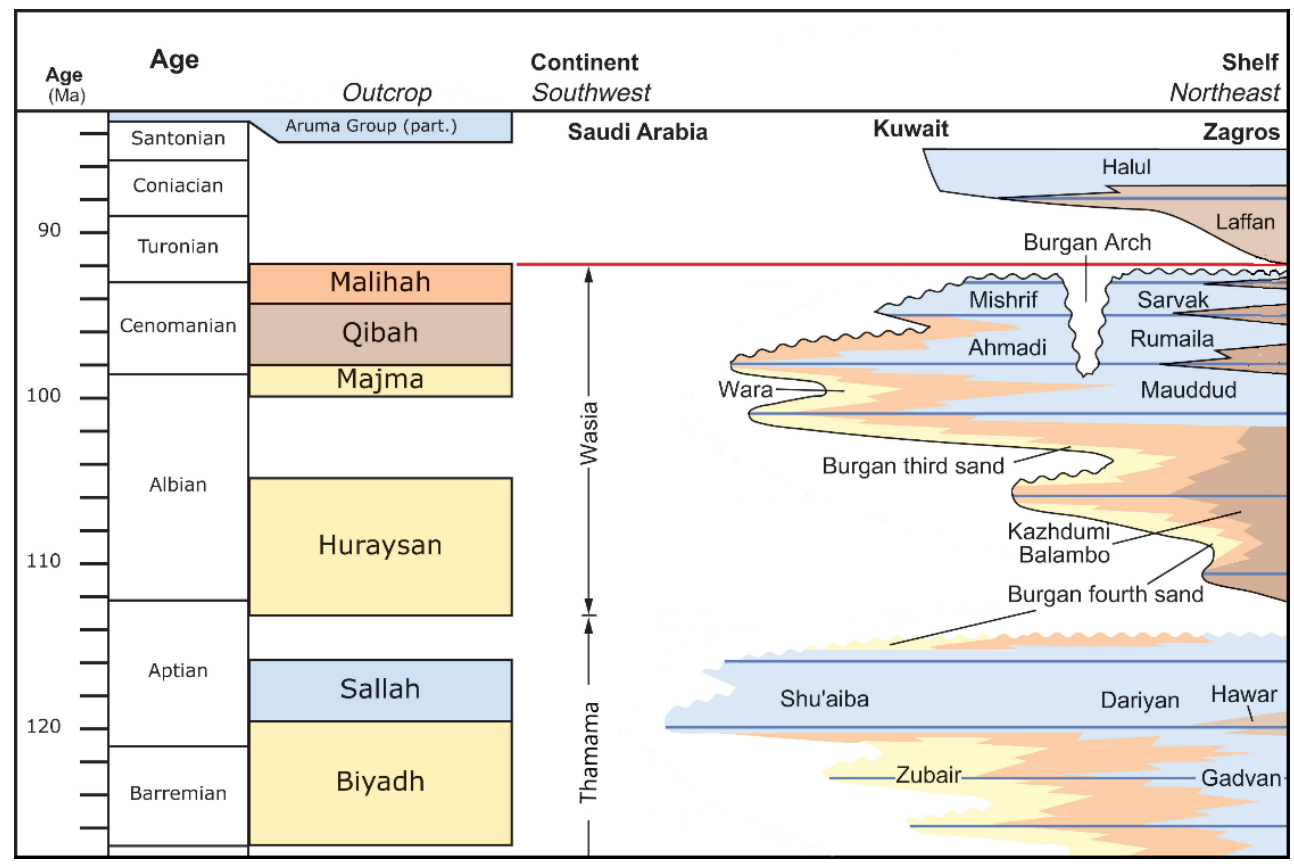

Figure 2. Stratigraphic chart of the Wasia Group and adjacent formations from the southwest to northeast of the Arabian Plate (modified from Reference [25]).

\subsection{Hydrogeology}

The main freshwater aquifer in the study area is composed of the Biyadh Formation of the Thamama Group and the Huraysan and Majma Formations of the Wasia Group (Figure 2). The intervening Sallah Formation of the Thamama Group is only a few meters thick and has similar hydraulic parameters to both the underlying and overlying aquifer components [25]. Piezometric heads of the Thamama Group and of the Wasia Group are indistinguishable in the study area. Most of the wells investigated partially penetrate the Wasia aquifer, while some of them were drilled through the Wasia strata into the Biyadh aquifer. Hence, for the purpose of this study, we will refer to this combined aquifer system as the Wasia aquifer or aquifer system.

The conceptual groundwater model (Figure 3) shows unconfined aquifers in the study area, while farther east, confined conditions prevail caused by increasingly shaly sediments acting as aquitards. Rain falls either on the outcrops of the aquifers or on a thin cover of Quaternary sediments, except for in the graben structure, where the Quaternary succession is thicker. While the vast majority of rainfall is lost to evapotranspiration, surface runoff is towards Wadi As-Sahba, where transmission losses routing downslope along the wadi add to groundwater recharge. Groundwater recharge through direct infiltration is very limited but has an additional component in irrigation return flow, the effect of which is the topic of this study. Except for evaporation [22], none of the components of the water balance has yet been specified for the Al Kharj area.

The Google Earth Map of the study area (Figure 4) shows an eastward decrease of the piezometric head from 340 m.a.s.l. to 270 m.a.s.l. (meters above the sea level) with the location of Al Kharj, the local wastewater treatment plant, and major agricultural irrigation zones (green to dark grey colored circles $=$ center pivots). Groundwater flow lines (Figure 4) indicate that the major groundwater flow is directed eastward along Wadi As-Sahba coinciding with the general flow system of the Wasia-Biyadh aquifer system on a regional scale. However, with the migration of farms increasing in size and abstraction eastward along the wadi to the east, groundwater is successively drawn also from both flanks towards the wadi. Concomitantly, an elongated cone of depression is formed, and the eastern end is located just outside the study area. It is also in this area that the Shu'aiba aquitard starts to effectively separate the Biyadh from the Wasia aquifer (Figure 3). Similarly, the Lower Aruma aquitard 
starts to separate the Wasia from the Aruma aquifer. In both cases, confined conditions are imposed on the aquifers and locally flowing wells are observed there.

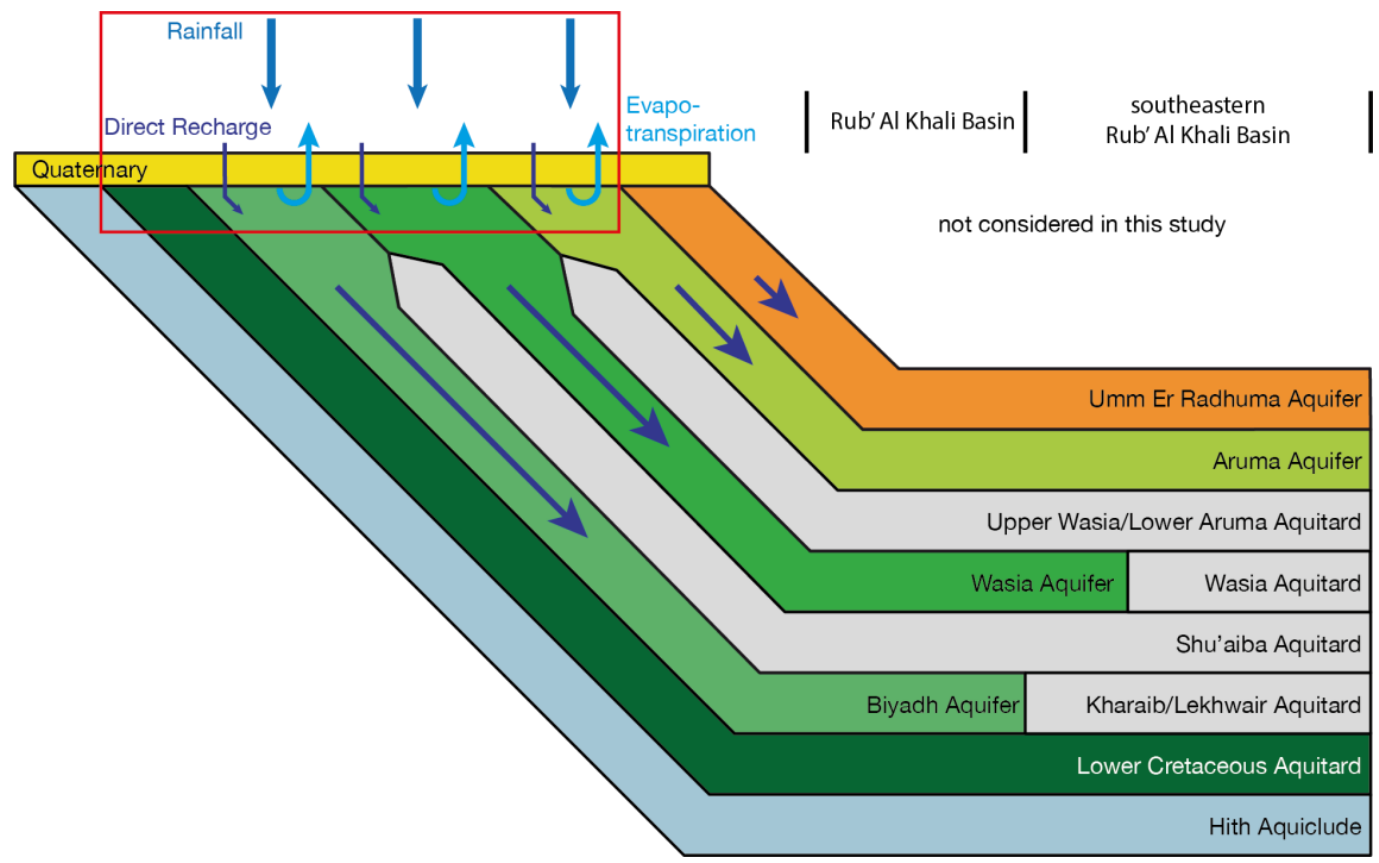

Figure 3. Conceptual aquifer model (not to scale) of the Al Kharj area (red box) with strata discussed in the text. Surface runoff is not shown in this figure.

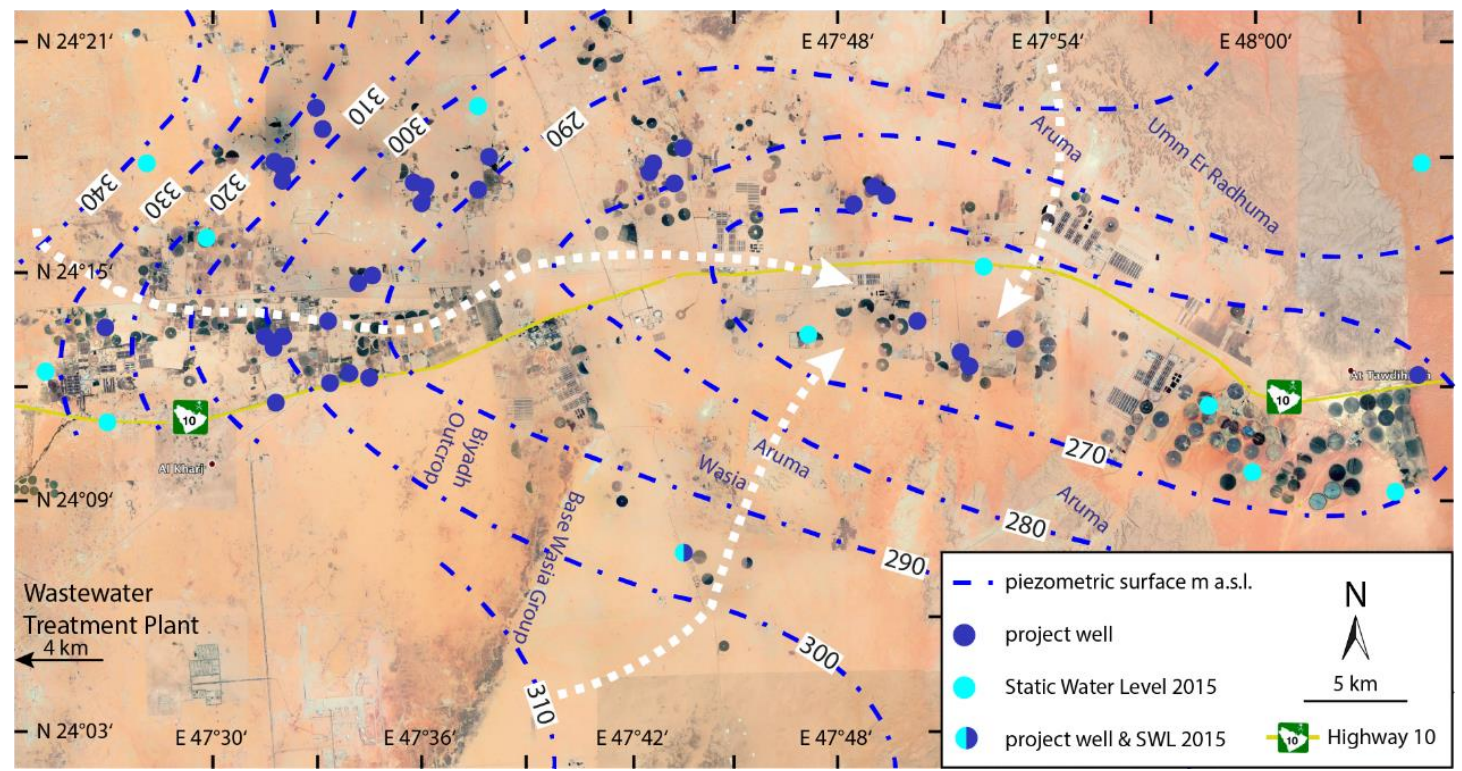

Figure 4. Google Earth map of the study area with sampled wells (dark blue dots) and piezometric heads as of 2015 (updated and modified from Reference [16]). Light blue dots indicate sites of static water level with performed water level measurements. Light blue/dark blue dots represent sampling and piezometric well sites. White, dashed lines are groundwater flow directions. Also shown are some major outcrop areas with dark grey to green colored radial-shaped irrigation areas (center pivots) and the position of the wastewater treatment plant south of Al Kharj.

The Biyadh aquifer is characterized by transmissivity values between $1.26 \times 10^{-3} \mathrm{~m}^{2} / \mathrm{s}$ to $9.7 \times 10^{-2} \mathrm{~m}^{2} / \mathrm{s}$ and a storage coefficient between $2.0 \times 10^{-4}$ and $9.0 \times 10^{-4}$ [26-28]. Porosity is 
very heterogeneous with values ranging from $1.1 \%$ to $40 \%$ with an average value between $23 \%$ and $31 \%$. Similarly, the permeability varies from 0.2 to $27,000 \mathrm{mD}$ with average values between 1700 and $4500 \mathrm{mD}$ [26-29].

The transmissivity of the overlying Wasia aquifer ranges from $1.5 \times 10^{-2} \mathrm{~m}^{2} / \mathrm{s}$ to $9.7 \times 10^{-2} \mathrm{~m}^{2} / \mathrm{s}$ and a storage coefficient between $2.3 \times 10^{-7}$ and $9.0 \times 10^{-4}$ [26-28] (Table 1). The Wasia aquifer consists of fossil water that has been recharged during cooler climatic conditions [16]. As ${ }^{14} \mathrm{C}$ dating of the underlying Triassic Jilh aquifer in northwestern Saudi Arabia resulted in a residence time between 25,000 and 35,000 years BP in the Late Pleistocene [30], and of the Paleozoic and Cretaceous aquifer systems in southwestern Saudi Arabia between 2400 and 35,000 years BP [31]. Hence, the Cretaceous Wasia aquifer in the study area was most likely recharged under similar climatic conditions during the Last Glacial Maximum (LGM). The study area lies within a large wadi system with natural springs, which are mostly dried out at present [13]. Porosity and permeability are within a similar range as the Biyadh aquifer [26-29].

Table 1. Hydraulic properties of the Biyadh and Wasia aquifers (modified from [26]).

\begin{tabular}{|c|c|c|c|}
\hline \multicolumn{4}{|c|}{ Biyadh } \\
\hline Hydraulic Property & Source & Value Range & Average Value \\
\hline \multirow{3}{*}{ Transmissivity, $\mathrm{T}$} & [26] & $1.7 \times 10^{-3}-9.0 \times 10^{-2} \mathrm{~m}^{2} / \mathrm{s}$ & $3.3 \times 10^{-2} \mathrm{~m}^{2} / \mathrm{s}$ \\
\hline & [27] & $1.26 \times 10^{-3}-7.0 \times 10^{-2} \mathrm{~m}^{2} / \mathrm{s}$ & $3.6 \times 10^{-2} \mathrm{~m}^{2} / \mathrm{s}$ \\
\hline & [28] & $1.5 \times 10^{-2}-9.7 \times 10^{-2} \mathrm{~m}^{2} / \mathrm{s}$ & $\mathrm{n} / \mathrm{a}$ \\
\hline Hydraulic conductivity, & [26] & $2.5 \times 10^{-4}-4.5 \times 10^{-4} \mathrm{~m} / \mathrm{s}$ & $3.0 \times 10^{-4} \mathrm{~m} / \mathrm{s}$ \\
\hline \multirow{2}{*}{$\begin{array}{l}\text { Hyarauic conauctivity, } \\
\mathrm{K}\end{array}$} & [27] & $3.3 \times 10^{-5}-3.0 \times 10^{-4} \mathrm{~m} / \mathrm{s}$ & $19 \times 10^{-4} \mathrm{~m} / \mathrm{s}$ \\
\hline & [26] & $2.3 \times 10^{-4}-9.0 \times 10^{-4}$ & $4.9 \times 10^{-4}$ \\
\hline \multirow[t]{2}{*}{ Storage coefficient, S } & [27] & $\mathrm{n} / \mathrm{a}$ & $3.2 \times 10^{-2}$ \\
\hline & [28] & $\mathrm{n} / \mathrm{a}$ & $2.0 \times 10^{-4}$ \\
\hline \multirow[t]{2}{*}{ Specific yield, $S_{y}$} & [26] & - & 5-15\% (estimated) \\
\hline & [25] & $1.1-36 \%$ & $23.3 \%$ \\
\hline \multirow[t]{3}{*}{ Porosity, $\Phi$} & [26] & $19-40 \%$ & $31 \%$ \\
\hline & [29] & $7-37 \%$ & $30 \%$ \\
\hline & [25] & $0.2-12,678 \mathrm{mD}$ & $1698 \mathrm{mD}$ \\
\hline \multirow[t]{4}{*}{ Permeability, k } & [26] & $240-11,100 \mathrm{mD}$ & $2500 \mathrm{mD}$ \\
\hline & [29] & $2000-27,000 \mathrm{mD}$ & $4500 \mathrm{mD}$ \\
\hline & & Wasia & \\
\hline & [26] & $1.7 \times 10^{-3}-9.0 \times 10^{-2} \mathrm{~m}^{2} / \mathrm{s}$ & $3.3 \times 10^{-2} \mathrm{~m}^{2} / \mathrm{s}$ \\
\hline \multirow[t]{2}{*}{ Transmissivity, $\mathrm{T}$} & {$[27]$} & $\mathrm{n} / \mathrm{a}$ & $3.2 \times 10^{-2} \mathrm{~m}^{2} / \mathrm{s}$ \\
\hline & [28] & $1.5 \times 10^{-2}-9.7 \times 10^{-2} \mathrm{~m}^{2} / \mathrm{s}$ & $\mathrm{n} / \mathrm{a}$ \\
\hline \multirow{3}{*}{$\begin{array}{l}\text { Hydraulic conductivity, } \\
\text { K }\end{array}$} & [26] & $2.5 \times 10^{-4}-4.5 \times 10^{-4} \mathrm{~m} / \mathrm{s}$ & $3.0 \times 10^{-4} \mathrm{~m} / \mathrm{s}$ \\
\hline & [27] & $1.5 \times 10^{-4}-4.9 \times 10^{-4} \mathrm{~m} / \mathrm{s}$ & $3.2 \times 10^{-4} \mathrm{~m} / \mathrm{s}$ \\
\hline & [26] & $2.3 \times 10^{-4}-9.0 \times 10^{-4}$ & $4.9 \times 10^{-4}$ \\
\hline \multirow[t]{2}{*}{ Storage coefficient, $\mathrm{S}$} & [27] & $\mathrm{n} / \mathrm{a}$ & $2.3 \times 10^{-7}$ \\
\hline & [28] & $\mathrm{n} / \mathrm{a}$ & $2.0 \times 10^{-4}$ \\
\hline \multirow[t]{2}{*}{ Specific yield, $\mathrm{S}_{\mathrm{y}}$} & [26] & - & 5-15\% (estimated) \\
\hline & [25] & $3.3-41.3 \%$ & $29.46 \%$ \\
\hline \multirow[t]{3}{*}{ Porosity, $\Phi$} & [26] & $19-40 \%$ & $31 \%$ \\
\hline & [29] & $7-37 \%$ & $30 \%$ \\
\hline & [25] & $0.7-15,388 \mathrm{mD}$ & $2994 \mathrm{mD}$ \\
\hline \multirow[t]{2}{*}{ Permeability, k } & [26] & $240-11,100 \mathrm{mD}$ & $2500 \mathrm{mD}$ \\
\hline & [29] & $2000-27,000 \mathrm{mD}$ & $4500 \mathrm{mD}$ \\
\hline
\end{tabular}

\section{Methodology}

The groundwater samples were collected from thirty-four (34) wells tapping the Wasia aquifer in the Al Kharj area from May 2018 to January 2019. Four samples from each well were stored in polyethylene (PE) bottles for anion and cation concentrations and trace element analysis. A total of 19 and 20 samples were analyzed for nitrate isotopes and tritium, respectively. The sampled 
wells are mainly used for irrigation and cattle watering. The PE bottles were pre-washed three times with deionized water to avoid sample contamination. The wells were purged for almost one hour before sampling to recover representative water samples. The piezometric water level, $\mathrm{pH}, \mathrm{EC}$, and temperature were measured in situ using multi-parameter meters (Hanna HI 9828). Water samples were filtered $(0.45 \mu \mathrm{m})$ to remove suspended solids and to limit the microbial activity. They were stored in a cooling box below $4{ }^{\circ} \mathrm{C}$ to preserve them for subsequent analysis of ions, nitrate isotopes, and tritium. Then, $\mathrm{HNO}_{3}$ was added to samples for the preservation of trace metals.

Hydrochemical analyses of major, minor, and trace elements were conducted in the Environmental and Hydrology Laboratory at the King Fahd University of Petroleum and Minerals (KFUPM), Dhahran, Saudi Arabia. Anion and cation concentrations in the $\mathrm{mg} / \mathrm{L}$ range were measured using the Ion Chromatograph Dionex ICS-6000 (IC) using the EPA 9056A standard method. Bicarbonate was measured using the titration method. The inductively coupled plasma mass spectrometry (iCAP RQ ICP-MS) technique with the EPA 6020A method was applied to measure trace elements within $\mu \mathrm{g} / \mathrm{L}$ range. Isotope analyses were conducted at the Environmental Isotope Laboratory, University of Waterloo, Ontario, Canada $\left({ }^{3} \mathrm{H},{ }^{15} \mathrm{~N}-\mathrm{NO}_{3}\right.$, and $\left.{ }^{18} \mathrm{O}-\mathrm{NO}_{3}\right)$. For nitrate isotopes, $\mathrm{NO}_{3}{ }^{-}$was converted to $\mathrm{NO}_{2}{ }^{-}$using a cadmium catalyst, then chemically converted to $\mathrm{N}_{2} \mathrm{O}$ and subsequently analyzed on a Trace Gas-GVI IsoPrime-IRMS (TG-IRMS) [32]. Tritium measurements were conducted using a liquid scintillation counting (LSC) technique. To increase the precision and lowering the detection limit, samples were counted after being enriched 15 times by electrolysis. This process resulted in a detection limit of $0.8 \pm 0.8$ tritium units (TUs).

Golden Software Surfer 14, Microsoft Excel 2013, Adobe Illustrator CC 2018, and OriginPro 2016 were used as principal software tools for processing and plotting the data and for map drawing.

\section{Results}

The hydrochemical composition and isotope ratios $\left({ }^{15} \mathrm{~N}-\mathrm{NO}_{3},{ }^{18} \mathrm{O}-\mathrm{NO}_{3}\right.$, and $\left.{ }^{3} \mathrm{H}\right)$ of groundwater samples from the Wasia aquifer in the study area are summarized in Table 2 . The average $\mathrm{pH}$ value was 7.6 and ranges from 6.8 to 8.0 . The average TDS value of these samples was $3030 \mathrm{mg} / \mathrm{L}$ with a minimum and maximum of $1100 \mathrm{mg} / \mathrm{L}$ and $7710 \mathrm{mg} / \mathrm{L}$, respectively. Wells with the highest TDS (4940-7710 mg/L) and nitrate concentrations (175-395 mg/L) were encountered in the most northern (WA08) and eastern parts (WB01, WB02, WB03, WB19) of the study area (Figure 5). Generally, Wasia groundwater from the $\mathrm{Al} \mathrm{Kharj}$ area was reported to be of the $\mathrm{Ca}-\mathrm{Mg}-\mathrm{SO}_{4}-\mathrm{Cl}$ type $[13,14]$. Based on the relative proportion between major elements, the studied borehole samples are classified into three groups as shown in the Piper diagram of Figure 6. Group 1 samples (WB02, WB03, WB05, WB06, WB07, WB13, WB14, WB17, WB18, WB19) were a Ca-SO ${ }_{4}-\mathrm{Cl}$ water type with a broad salinity range from 1580 to 7710 $\mathrm{mg} / \mathrm{L}$. Most of the water samples belonged to the second group (WB01, WB04, WB08, WB09, WB10, WB11, WB12, WB15, WB16, WB20, WA03, WA04, WA06, WA07, WA08, WA14) of the Ca-SO 4 type with a similar wide salinity range from 1240 to $6260 \mathrm{mg} / \mathrm{L}$. The third geochemical group (WA01, WA02, WA05, WA09, WA10, WA11, WA12, WA15) was less saline than the other two groups (1100-2400 mg/L) and displayed a $\mathrm{Ca}-\mathrm{Na}-\mathrm{SO}_{4}-\mathrm{Cl}$ water-type composition. $\mathrm{Ca}^{2+}$ represents the dominant cation (119-232 $\mathrm{mg} / \mathrm{L})$, followed by $\mathrm{Na}^{+}(115-254 \mathrm{mg} / \mathrm{L}), \mathrm{Mg}^{+}(36.7-70.6 \mathrm{mg} / \mathrm{L})$, and $\mathrm{K}^{+}(4.35-11.5 \mathrm{mg} / \mathrm{L})$. $\mathrm{SO}_{4}{ }^{2-}(234-500 \mathrm{mg} / \mathrm{L}), \mathrm{Cl}^{-}(136-348 \mathrm{mg} / \mathrm{L})$, and $\mathrm{HCO}_{3}{ }^{-}(153-193 \mathrm{mg} / \mathrm{L})$ are the dominant anions for Group 3. The Ca-Na-SO $-\mathrm{SO}-\mathrm{Cl}$ (Group 3) and $\mathrm{Ca}-\mathrm{SO}_{4}-\mathrm{Cl}$ (Group 1) water samples are located along a $\mathrm{W}-\mathrm{E}$ trending trench in the northern and central zone of the study area (Figure 5). The $\mathrm{Ca}-\mathrm{SO}_{4}-$ type groundwater (Group 2) is mainly encountered in the peripheral zone of the study area. 
Table 2. Hydrochemical parameters, stable isotope ratios of nitrates (15N-NO3 and 18O-NO3), and tritium measurements for selected groundwater samples from the Wasia aquifer in the study area.

\begin{tabular}{|c|c|c|c|c|c|c|c|c|c|c|c|c|c|c|c|c|c|c|c|c|c|c|c|c|c|c|c|c|c|c|c|}
\hline Well & $T$ & EC & TDS & TH & $\mathrm{Na}^{+}$ & $\mathrm{K}^{+}$ & $\mathrm{Mg}^{2+}$ & $\mathrm{Ca}^{2+}$ & $\mathrm{HCO}_{3}$ & & $\mathrm{Cl}^{-}$ & $\mathrm{NO}_{2}{ }^{-}$ & $\mathrm{Br}^{-}$ & $\mathrm{NO}_{3}{ }^{-}$ & $-\mathrm{SO}_{4}^{2-}$ & $-\mathrm{PO}_{4}{ }^{3-}$ & Li & B & Co & Mn & V & $\mathrm{Zn}$ & Fe & As & $\mathrm{Ni}$ & $\mathrm{Cu}$ & Mo & ${ }^{3} \mathrm{H}$ & $\delta^{15} \mathrm{~N}$ & $\mathcal{\delta}^{18} \mathrm{O}$ & er Type \\
\hline Units & ${ }^{\circ} \mathrm{C}$ & $\mu \mathrm{S} / \mathrm{cl}$ & $\mathrm{n} \mathrm{mg/L}$ & $\mathrm{mg} / \mathrm{L}$ & $\mathrm{mg} / \mathrm{L}$ & $\mathrm{mg} / \mathrm{L}$ & $\mathrm{mg} / \mathrm{L}$ & $\mathrm{mg} / \mathrm{L}$ & $\mathrm{mg} / \mathrm{L}$ & $\mathrm{mg} / \mathrm{L}$ & $\mathrm{mg} / \mathrm{L}$ & $\mathrm{mg} / \mathrm{L}$ & $\mathrm{mg} / \mathrm{L}$ & $\mathrm{mg} / \mathrm{L}$ & $\mathrm{mg} / \mathrm{L}$ & $\mathrm{mg} / \mathrm{L}$ & $\mu \mathrm{g} / \mathrm{L}$ & $\mu \mathrm{g} / \mathrm{L}$ & $\mu \mathrm{g} / \mathrm{L}$ & $\mu \mathrm{g} / \mathrm{L}$ & $\mu \mathrm{g} / \mathrm{L}$ & $\mu \mathrm{g} / \mathrm{L}$ & $\mu \mathrm{g} / \mathrm{L}$ & $\mu \mathrm{g} / \mathrm{L}$ & $\mu \mathrm{g} / \mathrm{L}$ & $\mu \mathrm{g} / \mathrm{L}$ & $\mu \mathrm{g} / \mathrm{L}$ & $\begin{array}{l} \pm 0.8 \\
\text { T.U. }\end{array}$ & $\begin{array}{l}\text { AIR } \pm \\
0.5 \% \text { o }\end{array}$ & $\begin{array}{c}\text { VSMOW } \\
\pm 1 \% \text { o }\end{array}$ & \\
\hline WB01 7.3 & 31.9 & 6809 & 5860 & 1850 & 433 & 4.19 & 159 & 479 & 188 & 1.8 & 1170 & ND & 5.5 & 358 & 1330 & ND & 0.9 & 1150 & 0.81 & 3.05 & 3.24 & 5.52 & 3040 & 0.23 & 0.51 & 1.65 & 7.39 & $<0.8$ & 5.9 & 25.8 & $\mathrm{Ca}-\mathrm{SO}_{4}$ \\
\hline WB02 7.5 & 32.5 & 8007 & 7330 & 2740 & 359 & 4.43 & 212 & 747 & 77.0 & 1.7 & 1690 & ND & 5.9 & 359 & 974 & ND & ND & 449 & 1.10 & 4.24 & 3.87 & 3.32 & 4120 & 0.27 & ND & 1.72 & 4.05 & $<0.8$ & & 24.2 & $\mathrm{Ca}-\mathrm{SO}_{4}-\mathrm{Cl}$ \\
\hline B03 7.6 & 0.5 & 8673 & 710 & & & 6.9 & 24 & 75 & 89. & 1.8 & 1840 & $\mathrm{~N}$ & & & 1190 & ND & $\mathrm{ND}$ & & 1.00 & 8.83 & 2.60 & $\mathrm{ND}$ & 4050 & 0.21 & 0.44 & 2.74 & & 0. & & & \\
\hline B04 7.6 & 6.9 & 2317 & 1990 & 686 & 123 & 6.36 & 57.3 & 180 & 161 & 1.2 & 362 & ND & 2.6 & 3.26 & 405 & ND & 0.5 & 328 & 0.41 & 88.2 & 0.15 & 1.96 & 1140 & ND & 0.92 & 11.15 & 5.96 & $<0$ & & & $\mathrm{Ca}-\mathrm{SO}_{4}$ \\
\hline WB05 7.6 & 28.4 & 3684 & 3370 & 1540 & 158 & 3.30 & 121 & 419 & 147 & 1.4 & 375 & ND & 2.3 & 25.3 & 1290 & ND & 0.5 & 465 & 0.54 & 4.33 & 2.30 & ND & 1870 & 0.09 & ND & 0.35 & 3.48 & $<0.8$ & 10.7 & 11.2 & $\mathrm{Ca}-\mathrm{SO}_{4}-\mathrm{Cl}$ \\
\hline WB06 7.8 & 27.6 & 4246 & 3930 & 1670 & 207 & 5.69 & 138 & 441 & 118 & 1.6 & 449 & ND & 2.4 & 62.0 & 1440 & ND & 0.5 & 469 & 0.55 & 8.29 & 0.35 & 48.8 & 1990 & ND & ND & 2.75 & 6.78 & $<0.8$ & 6.6 & 9.5 & $\mathrm{Ca}-\mathrm{SO}_{4}-\mathrm{Cl}$ \\
\hline WB07 7.9 & 31.9 & 1811 & 1580 & 734 & 67.0 & 1.98 & 60.1 & 195 & 150 & 1.5 & 164 & ND & ND & 4.97 & 558 & ND & 0.5 & 273 & 2.17 & 2.57 & 1.26 & ND & 702 & ND & 1.43 & 0.82 & 4.06 & $<0.8$ & & 16.7 & $\mathrm{Ca}-\mathrm{SO}_{4}-\mathrm{Cl}$ \\
\hline WB08 7.9 & 30.3 & 7585 & & & & 100 & & & & 1.8 & 1320 & & 5.5 & & 163 & & م & 1430 & 1.34 & & 3.04 & ND & 2560 & & & & & & & & \\
\hline B09 7.7 & 30.9 & 3944 & 3320 & 1200 & 229 & 4.61 & 105 & 307 & 154 & 1.2 & 612 & ND & 2.7 & 111 & 779 & ND & 0.0 & 555 & 0.32 & 0.00 & 1.79 & 0.00 & 1110 & 0.04 & 0.00 & 0.69 & 3.45 & & & 23 & $\mathrm{Ca}-\mathrm{SO}_{4}$ \\
\hline WB10 7.7 & 31.6 & 2271 & 1960 & 712 & 116 & 1.09 & 61.7 & 183 & 148 & 1.2 & 310 & ND & 2.3 & 47.5 & 414 & ND & 0.5 & 319 & 0.15 & 0.00 & 2.13 & 0.00 & 581 & 0.16 & 0.00 & 0.19 & 2.94 & $<0.8$ & 7.0 & 19 & $\mathrm{Ca}-\mathrm{SO}_{4}$ \\
\hline WB11 7.7 & 32.4 & 3433 & 2900 & 1010 & 199 & 3.52 & 86.7 & 262 & 145 & 1.2 & 491 & ND & 2.5 & 97.4 & 682 & ND & 0.5 & 531 & 0.28 & 0.54 & 1.45 & 0.00 & 940 & 0.10 & 0.00 & 0.39 & 2.77 & $<0.8$ & 7.0 & 17.4 & $\mathrm{Ca}-\mathrm{SO}_{4}-\mathrm{Cl}$ \\
\hline WB12 7.8 & 34.8 & 1487 & 1240 & 473 & 67.0 & 2.39 & 41.2 & 122 & & 1.2 & 162 & ND & 1.2 & 8.54 & 278 & ND & & & 0.24 & 8.44 & 0.72 & 0.00 & 459 & 0.00 & 0.40 & 0.13 & 4.19 & $<0.8$ & & & \\
\hline & 27.6 & 4387 & & 1650 & 224 & 4.79 & 138 & 434 & & 1.6 & & ND & & & 1450 & $\mathrm{~N}$ & & & 0.42 & & 1.93 & 4.87 & 1640 & & 0.71 & & & & & & \\
\hline 3148.0 & 28.1 & 3711 & 3310 & 1440 & 167 & 3.41 & 112 & 39 & & 1.5 & 380 & ND & & 28.9 & 122 & ND & 0.5 & 383 & 0.46 & 6.20 & 1.35 & 40.7 & 1700 & 0.08 & & 1.93 & 5.39 & & & & \\
\hline WB15 7.7 & 34.2 & 3458 & 2900 & 1070 & 184 & 2.80 & 84.1 & 291 & 14 & 1.2 & 516 & ND & 2.7 & 76.7 & 681 & ND & 0.5 & 363 & 0.29 & 1.04 & 1.69 & 0.00 & 1140 & 0.15 & 0.00 & 0.39 & 3.21 & $<0.8$ & & 18. & $\mathrm{Ca}-\mathrm{SO}_{4}$ \\
\hline WB16 7.8 & 31.9 & 3327 & 2850 & 1030 & 159 & 3.55 & 83.7 & 273 & 14 & 1.2 & 497 & ND & 2.8 & 63.1 & 591 & ND & 0.5 & 2 & 0.23 & ND & 0.67 & ND & 870 & ND & 0.35 & 0.11 & 7.11 & $<0.8$ & & 2 & $\mathrm{Ca}-\mathrm{SO}_{4}$ \\
\hline B17 7.9 & 29.0 & 2912 & 2540 & 1120 & & 3.11 & 87. & 304 & & 1.6 & 282 & ND & 2.2 & 36.8 & 906 & ND & 0.5 & & 0.64 & ND & 0.72 & ND & 989 & $\mathrm{~N}$ & ND & 0.37 & 5.08 & & & & ${ }_{4}-\mathrm{Cl}$ \\
\hline & 29.7 & 2595 & 2250 & 999 & & 1. & 76.6 & 274 & & & & & 2 & 21.5 & & & ND & & & 7.7 & 23 & ND & 96 & & & & & & & & \\
\hline 3197.9 & 30.1 & 5588 & & 1810 & & 3 . & 1 & & & & & & & & & & $\mathrm{NI}$ & & & & 54 & $\mathrm{~N}$ & 1630 & & & & & & & & \\
\hline WB20 7.9 & 30.7 & 1680 & 1450 & 535 & 76. & 1.38 & 47. & 13 & 1 & 1. & 2 & $\mathrm{ND}$ & ND & 18.4 & 32 & $\mathrm{ND}$ & 0.4 & & 09 & 83 & 3.20 & ND & 419 & 0.30 & $\mathrm{ND}$ & 0.50 & 5.01 & $<0.8$ & 7.9 & 17.8 & $\mathrm{Ca}-\mathrm{SO}_{4}$ \\
\hline WA01 7.5 & 35.0 & 1536 & 1100 & 44 & 1 & 5.47 & 36 & 1 & & 1. & 1 & ND & 0. & 2. & 23 & ND & 66.3 & & 42 & 27 & 25 & ND & 68.2 & 0.13 & 09 & 0.42 & 7.62 & & & - & $\mathrm{Ca}-\mathrm{Na}-\mathrm{SO}_{4}-\mathrm{Cl}$ \\
\hline & 36.0 & 2504 & & 694 & & 5.53 & & 1 & & 0.85 & & ND & & & 41 & & 68.5 & & & 2.48 & 2.30 & 1.7 & 72.8 & & & & & . & - & - & $\mathrm{O}_{4}-\mathrm{Cl}$ \\
\hline & 32.5 & 5255 & 4920 & 1690 & 395 & 7.40 & 134 & 457 & & 1.4 & & ND & 2. & 25.2 & 7 & & 71.4 & & 1.50 & 20.9 & 3.03 & ND & 110 & 0.21 & 0.32 & 98 & & . & 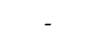 & - & $\mathrm{Ca}$ \\
\hline 47.2 & 29.5 & 3746 & & $14 \mathrm{C}$ & & 5. & & & & & & & & & & & & & & & & 36 & 83.7 & & & & & & & & \\
\hline A05 7.3 & 32.0 & 223 & & 6. & & 4. & & & & 0. & & & & & 3 & $\mathrm{~N}$ & & & 44 & & & 2. & 33.7 & & & & & . & - & - & $\mathrm{O}_{4}-\mathrm{Cl}$ \\
\hline 67.4 & 31 & 2170 & & 7 & & 11 & & & & & & & & & 5 & 8. & & & & & & 0. & 38 & 0 & & & & - & & - & \\
\hline WA07 6.9 & 32.3 & 2440 & 20 & 90 & & 5. & & & & & & 0.1 & & & 72 & 7 & & & & & & & 41 & & & & 5. & . & - & - & \\
\hline WA08 6.9 & 31.4 & 1310 & 1860 & 754 & 207 & 6.96 & 62.1 & 200 & 6 & 1.25 & 18 & 0.2 & 1.0 & 1.94 & 625 & ND & 14.8 & 161 & 2.74 & 1.71 & 0.37 & 2.82 & 87.3 & 0.02 & 1.72 & 0.10 & 1.13 & - & - & - & $\mathrm{Ca}-\mathrm{SO}_{4}$ \\
\hline WA09 7.2 & 32.8 & 2970 & & 869 & 254 & 6.71 & & & & & & & & 10.3 & & & & & & & & & & & & & & - & 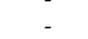 & . & $\mathrm{O}_{4}-\mathrm{Cl}$ \\
\hline & 35. & 197 & & 5 & & 6. & & & & & & & & $<$ & & & & & & & & & & & & & & & & & \\
\hline & & 23 & & 7 & & & & & 1 & & 2 & & & 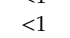 & & & & & & & & $\mathrm{N}$ & 3 & & & & & . & 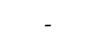 & - & \\
\hline WA12 7.5 & 36.7 & 2310 & 1810 & 680 & 207 & 6.60 & 59.2 & 175 & 164 & 0.9 & 25 & ND & 1. & 7.97 & 419 & ND & 68.4 & 42 & 0.53 & 1.18 & 3.19 & ND & 20.5 & 0.24 & 0.23 & 0.94 & 4.67 & - & - & - & $\mathrm{Ca}-\mathrm{Na}-\mathrm{SO}_{4}-\mathrm{Cl}$ \\
\hline A14 7.4 & 28.5 & 4040 & 3580 & 1510 & 329 & 7.22 & 118 & 411 & 137 & 1.91 & 335 & ND & 2.25 & 14.7 & 1260 & ND & 86.8 & 693 & 3.60 & 5.09 & 1.41 & ND & 114 & 0.05 & 1.54 & 2.59 & 10.4 & - & - & - & $\mathrm{Ca}-\mathrm{SO}_{4}$ \\
\hline WA15 7.7 & 31.4 & 2240 & 1720 & 639 & 201 & 5.42 & 53.0 & 168 & 164 & 0.97 & 244 & 0.1 & 1.12 & 8.16 & 377 & ND & 63.2 & 403 & 0.52 & 0.36 & 4.02 & ND & 52.9 & 0.35 & 0.36 & 0.98 & 5.13 & 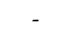 & - & - & $\mathrm{Ca}-\mathrm{Na}-\mathrm{SO}_{4}-\mathrm{Cl}$ \\
\hline
\end{tabular}

Notes: EC: Electrical Conductivity; TDS: Total Dissolved Solids; TH: Total Hardness; T.U.: Tritium Units; AIR: Atmosphere of Earth; VSMOW: Vienna standard mean ocean water. 


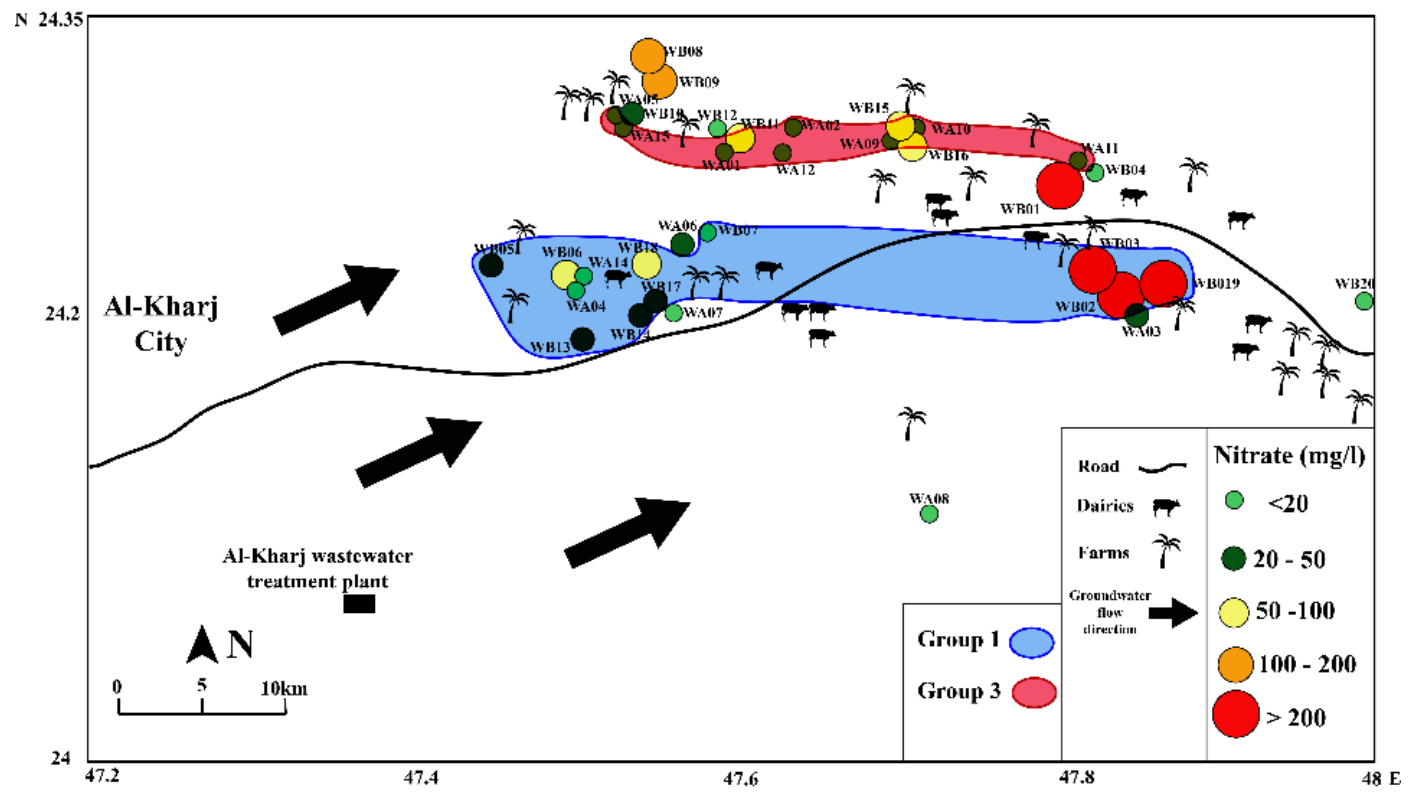

Figure 5. Map of measured nitrate concentrations in the Wasia aquifer and land use in the Al Kharj study area. Also shown is the attribution of water samples to Groups 1 and 3 according to the Piper diagram (Figure 6). All other shown sample sites belong to Group 2.

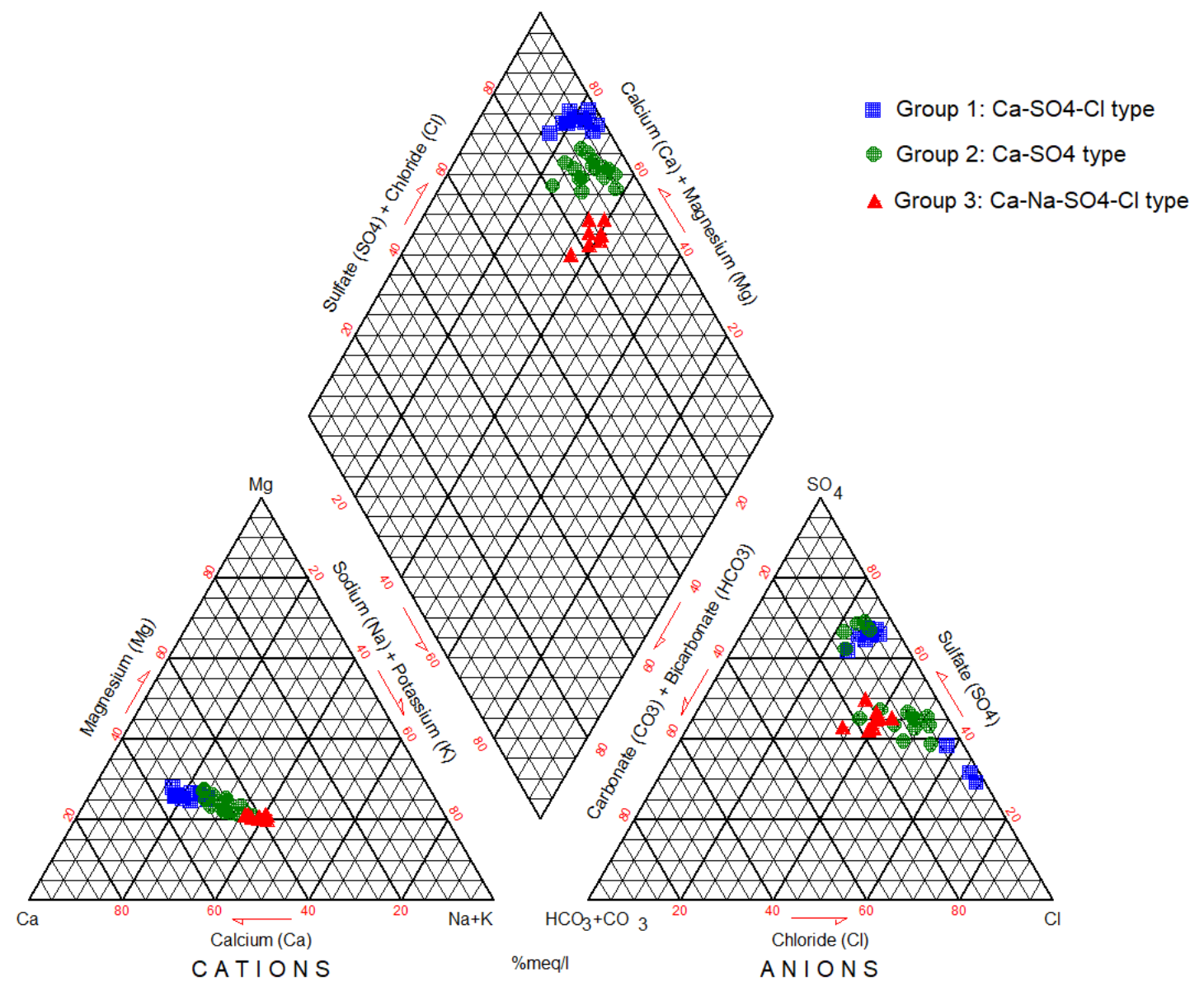

Figure 6. Piper classification diagram with the three hydrochemical groups of groundwater identified from the Wasia aquifer in the Al Kharj area. 
The $\mathrm{NO}_{3}{ }^{-}$concentrations reached up to $395 \mathrm{mg} / \mathrm{L}$ in some wells with an average of $68.2 \mathrm{mg} / \mathrm{L}$. Spatially, wells with high nitrate concentrations $(>100 \mathrm{mg} / \mathrm{L})$ are distributed in the eastern (WB01, WB02, WB03, and WB19) and northwestern (WB08 and WB09) parts that are dominated by farms (Figure 4). Eleven out of 34 analyzed Wasia groundwater samples exceed the WHO drinking water guideline value for nitrate of $50 \mathrm{mg} / \mathrm{L}$ [33]. Nitrate concentrations below the WHO guideline are mostly encountered in the peripheral zone of the study area with the highest sample density in the southwest (Figure 5). Li and $\mathrm{Fe}$ are the most dominant trace elements in present fluid samples with an average of $445 \mu \mathrm{g} / \mathrm{L}, 24.5 \mu \mathrm{g} / \mathrm{L}$, and $963 \mu \mathrm{g} / \mathrm{L}$, respectively. Nitrate isotope ratios from the Wasia aquifer ranged from $5.5 \%$ o to $11.3 \%$ o versus AIR (atmosphere of Earth) and from $8.6 \%$ o to $25.8 \%$ o versus VSMOW (Vienna standard mean ocean water) for $\delta^{15} \mathrm{~N}-\mathrm{NO}_{3}$ and $\delta^{18} \mathrm{O}-\mathrm{NO}_{3}$, respectively.

Two out of 20 analyzed samples in the northwestern (WB08) and eastern area (WB03) showed tritium $\left({ }^{3} \mathrm{H}\right)$ concentrations of $0.82 \pm 0.8 \mathrm{TU}$ and $0.98 \pm 0.8 \mathrm{TU}$, respectively, while the remaining samples presented readings below the detection limit of $0.8 \mathrm{TU}$ (Table 2). The analytical results are discussed in the upcoming section.

\section{Discussion}

\subsection{Tritium for Recent Recharge Assessment}

Tritium analyses of precipitation samples from 12 rainfall events in Riyadh yielded concentrations between 2.8 and 6.4 tritium units (TU) which are close to the natural background of a few TU [34]. For the present Wasia groundwater samples (except WB03 and WB08), ${ }^{3} \mathrm{H}$ concentrations below the detection limit of $0.8 \mathrm{TU}$ implied the absence of recent recharge with a residence time beyond the 1950s or 1960s. It is very likely, that the Cretaceous Wasia aquifer was recharged during the Last Glacial Maximum in the Late Pleistocene, as documented for the Triassic Jilh aquifer in northwestern Saudi Arabia [30], for the lower and upper Wajid aquifers, and the combined Wasia-Biyadh-Aruma aquifer in southwestern Saudi Arabia [31]. A second option could be the mixture of a recent surface water source with fossil groundwater. The samples WB03 and WB08 with detectable tritium concentrations $(0.98 \pm 0.8 \mathrm{TU}$ and $0.82 \pm 0.8 \mathrm{TU}$, respectively, Table 2$)$ were characterized by most elevated salinity $(6260-7710 \mathrm{mg} / \mathrm{L})$, nitrate $(175-395 \mathrm{mg} / \mathrm{L})$, and boron $(780-1430 \mu \mathrm{g} / \mathrm{L})$ concentrations. This combination suggests the local influx of evaporated irrigation water with remnants of dissolved fertilizer into the Wasia groundwater system in the vicinity of these two wells. It can be concluded that samples with tritium concentrations below $0.8 \mathrm{TU}$ are composed of fossil water that has likely been recharged during the Late Pleistocene, while the samples "WB03" and "WB08" could present some additional atmospheric influx from infiltrated irrigation water.

As the applied LSC technique is limited to a detection limit to $0.8 \mathrm{TU}$, more advanced techniques like helium $\left({ }^{3} \mathrm{He}\right)$ ingrowth may be needed to reach higher precision. The helium ingrowth method depends on measuring helium concentrations that decay from tritium after storing the groundwater sample for several months and then normalized to a reference date to reconstruct the tritium content. This method can reach a detection limit of up to $0.005 \mathrm{TU}$ [3].

\subsection{Possible Sources of Nitrate}

Ammonium, nitrate fertilizers, manures or animal waste as potential anthropogenic sources and nitrogen input by precipitation/atmospheric deposition or from interaction with rock or soil as natural sources for the accumulation of nitrate in the Wasia aquifer in the study area (Figures 7 and 8) are discussed in this chapter. 


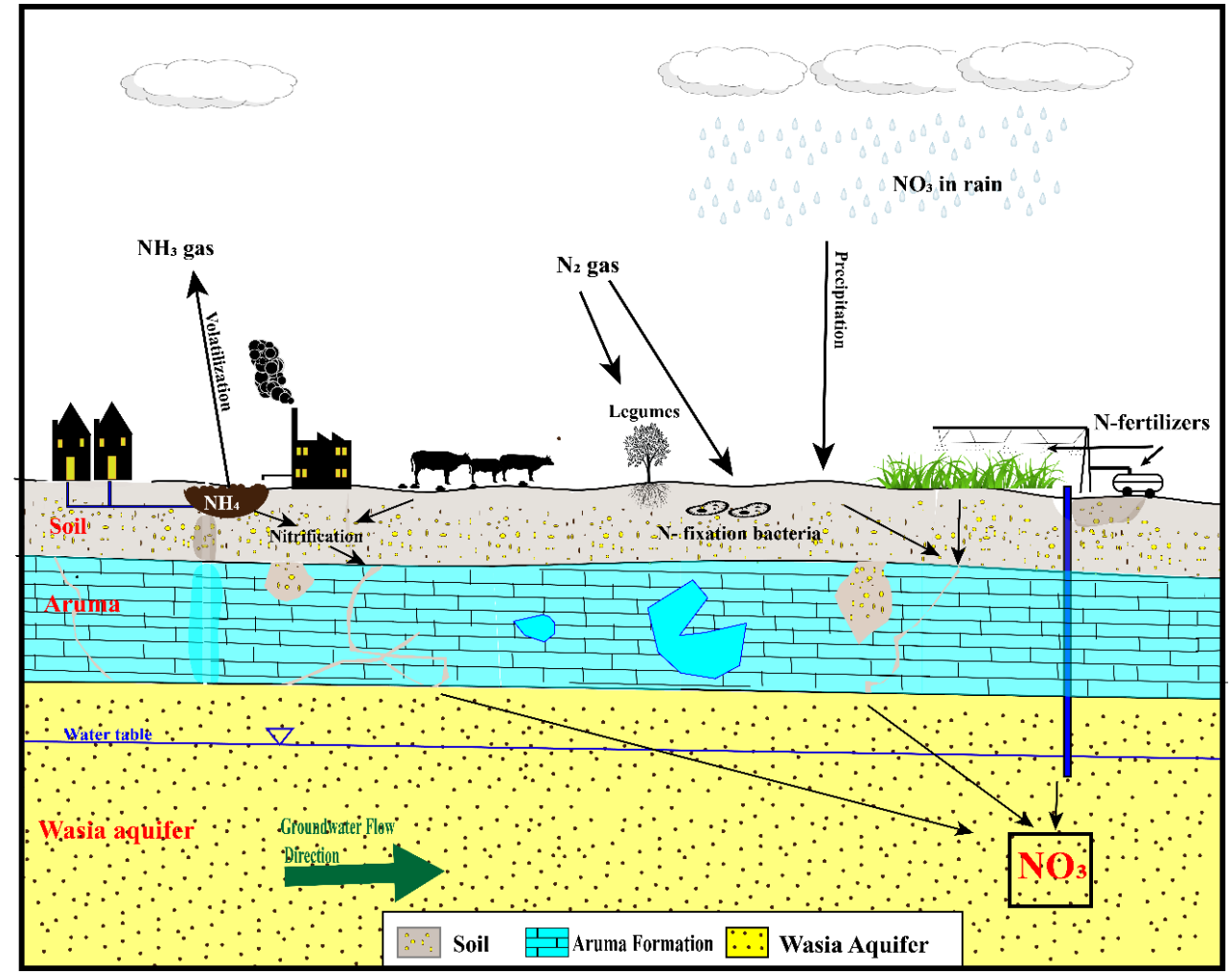

Figure 7. Schematic diagram of potential natural and anthropogenic sources for nitrate in the Al Kharj area.

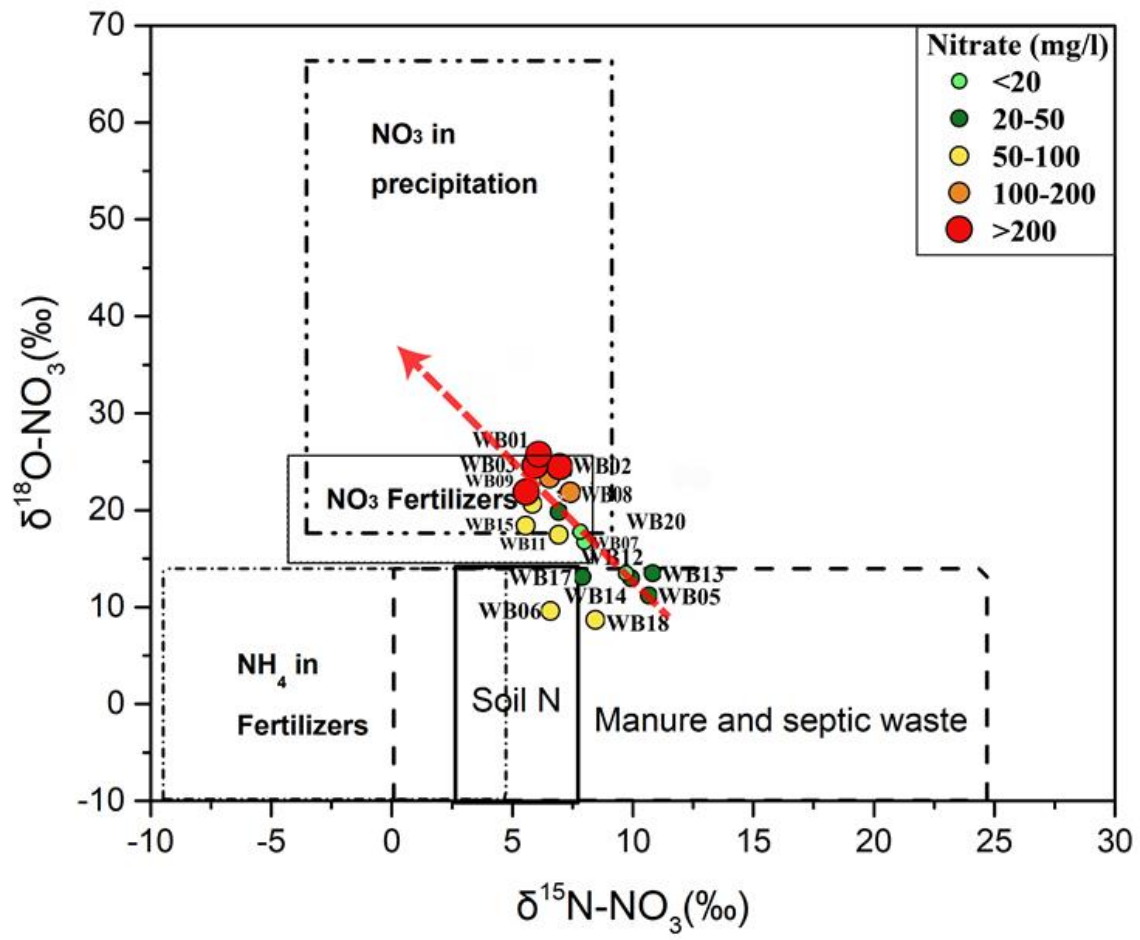

Figure 8. Relationship between $\delta^{15} \mathrm{~N}_{\mathrm{NO} 3}$ and $\delta^{18} \mathrm{O}_{\mathrm{NO} 3}$ isotopes of analyzed groundwater samples from the study area. General ranges for the isotopic compositions of different types of common nitrate sources were adapted from Reference [35]. The increasing nitrification of Wasia groundwater by the influx of fertilizer is shown by the red arrow. 


\subsubsection{Fertilizers}

As the study area is dominated by agricultural activities, several fertilizers are added to the soil. It is critical to differentiate between synthetic nitrate fertilizers by industrial fixation of atmospheric nitrogen and nitrate resulting from ammonium fertilizers. The former generally have a $\delta^{15} \mathrm{~N}$ range of $-5 \%$ o to $+8 \%$ ond higher $\delta^{18} \mathrm{O}$ of $+17 \%$ o to $+25 \%$, as it is derived from atmospheric oxygen. The influx of ammonium fertilizer causes a wider range of $\delta^{15} \mathrm{~N}_{\mathrm{NO} 3}$ due to the various sources $(-10 \%$ o to $+5 \%$ o) and more depleted ratios for $\delta^{18} \mathrm{O}_{\mathrm{NO} 3}(-15 \%$ o to $+15 \%$ o $)[6]$.

In the present case study, the combination of most depleted $\delta^{15} \mathrm{~N}_{\mathrm{NO} 3}$ and most elevated $\delta^{18} \mathrm{O}_{\mathrm{NO}}$ ratios for recovered groundwater samples in the most northern (WB08, WB09) and eastern (WB01, WB02, WB03, WB19) section of the study area (Figures 8 and 9) suggest that synthetic fertilizers represent the main local source for nitrate. Where ammonium fertilizers generally have a lower range of $\delta^{18} \mathrm{O}_{\mathrm{NO} 3}, 63 \%$ of the studied samples fall within the area of the isotopic composition of synthetic nitrate fertilizers ( $+5.5 \%$ o to $+8.0 \%$ o and $+16.7 \%$ o to $+25.8 \%$ o for $\delta^{15} \mathrm{~N}$ and $\delta^{18} \mathrm{O}$, respectively). In contrast, the combination of lower saline conditions (TDS $=1400-2000 \mathrm{mg} / \mathrm{L}$ ), elevated $\delta^{15} \mathrm{~N}_{\mathrm{NO}}$ and depleted $\delta^{18} \mathrm{O}_{\mathrm{NO} 3}$ ratios in the western part of the study area (western flank of Water Group 1 and 3 from Section 4 and in Figure 4) indicate the presence of pristine Wasia groundwater with minimum alteration by anthropogenic factors. The negative isotope trend in Figure 8 illustrates the increasing nitrification of the Wasia aquifer by the influx of fertilized irrigation water.
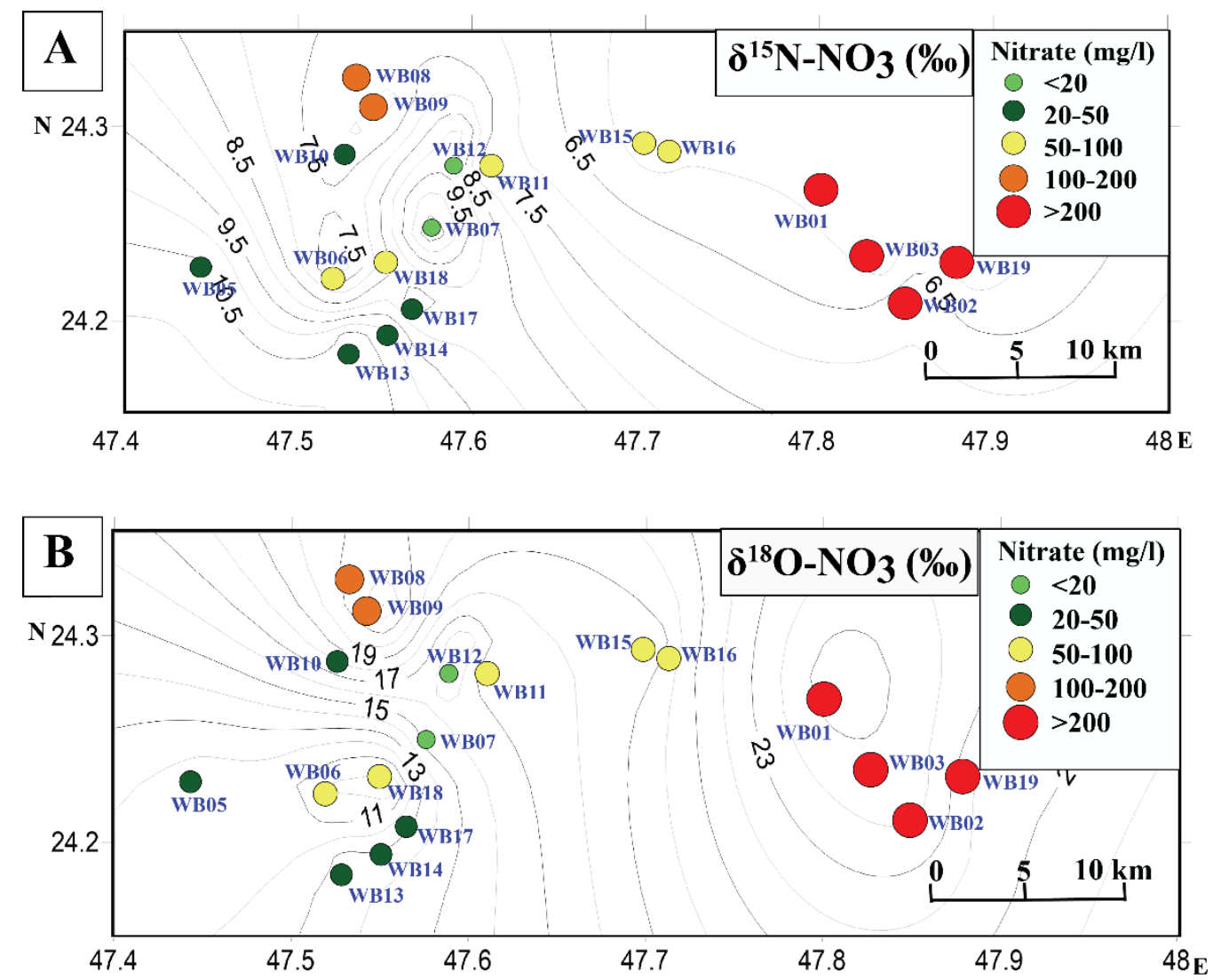

Figure 9. Spatial distribution of (A) $\delta^{15} \mathrm{~N}$ and (B) $\delta^{18} \mathrm{O}$ of nitrate from Wasia groundwater wells in the Al Kharj area.

Boron occurs naturally in groundwater, but high levels of boron may indicate anthropogenic sources such as landfill leachate, drainage from coal mines and mining related wastes, and sewage effluent due to the fact of its presence in detergents. Boron can be concentrated in agricultural as it is a minor constituent in fertilizers and pesticides [36,37]. Although none of the water samples 
exceeded the recent WHO recommendation of $2400 \mu \mathrm{g} / \mathrm{L}$ for boron in drinking water [38], the boron concentrations between 520 and $1430 \mu \mathrm{g} / \mathrm{L}$ for seven samples (WB01, WB03, WB08, WB09, WB11, WB13, and WB19) were above the recommended WHO norm from $2017 \mathrm{of} 500 \mu \mathrm{g} / \mathrm{L}$ [38]. These wells are distributed in the northwestern and eastern parts of the study area and are positively linked to wells with elevated nitrate concentrations. The presence of boron in these wells suggests the influx of fertilizers in these parts of the study area, as previously illustrated by nitrogen and oxygen isotopes. Two of the potential fertilizer-affected samples (WB03, WB08) also show relatively elevated tritium concentrations, which suggest the infiltration of recent water into the Wasia aquifer.

\subsubsection{Atmospheric Deposition}

Rainwater analysis in the study region showed average concentrations of $4.26 \mathrm{mg} / \mathrm{L}$ for $\mathrm{NO}_{3}{ }^{-}$ and $17.4 \mathrm{mg} / \mathrm{L}$ for $\mathrm{Cl}^{-}$[39]. A precipitation rate of $75 \mathrm{~mm}$ per year [16] would result in an annual deposition of around $3.2 \mathrm{~kg} / \mathrm{ha}$ of $\mathrm{NO}_{3}{ }^{-}$which will possibly be taken up by vegetation, soil bacteria, or might percolate to the water table. As part of a mass balance, this calculated amount of nitrate alone does not account for the entire nitrate budget.

With an annual average recharge of 5 to $10 \mathrm{~mm}$ [16] and elevated evaporation rates that reach $2000 \mathrm{~mm} /$ year [16,22], evaporation is anticipated to play a major role in nitrate accumulation in the Wasia aquifer. Considering exclusively the effect by evaporation, mentioned recharge rates, and an average annual rainfall rate of $75 \mathrm{~mm}$ in this area [16], an evaporation rate of about $87 \%$ to $93 \%$ is required to decrease the precipitated rainwater volume to the recharge amount. Considering the $\mathrm{Cl}^{-}$ concentration as a measure for the rate of evaporation, the analyzed $\mathrm{Cl}^{-}$concentrations between 136 and $1840 \mathrm{mg} / \mathrm{L}$ in this groundwater could result from an evaporation rate of $87 \%$ to $99 \%$ of rainwater with $17.4 \mathrm{mg} / \mathrm{L}$ of $\mathrm{Cl}^{-}$. A concentration of 33 to $426 \mathrm{mg} / \mathrm{L}$ of nitrate might result from this simulated scenario of evaporation, which agrees with measured nitrate concentrations in the studied samples. The detected linear relationship between $\mathrm{Cl}^{-}$and $\mathrm{NO}_{3}{ }^{-}$concentrations, especially for most saline samples suggests the influence of evaporation as an essential contributor for $\mathrm{Cl}^{-}$and $\mathrm{NO}_{3}{ }^{-}$enrichment in the studied Wasia aquifer (Figure 10a. The excellent correlation between $\mathrm{Cl}^{-}$as a conservative element and $\mathrm{Ca}^{2+}$ as a reactive element confirms the lack of secondary water-rock alteration processes (Figure 10b). According to stable isotope ratios of nitrate $\left({ }^{15} \mathrm{~N}-\mathrm{NO}_{3}\right.$ and $\left.{ }^{18} \mathrm{O}-\mathrm{NO}_{3}\right), 58 \%$ of these nitrate concentrations (11 out of 19 samples) are related to atmospheric deposition (Table 2 and Figure 8). Atmospheric deposition is apparently a major contributor to the elevated nitrate concentrations in the Wasia aquifer, although reduced amounts by vegetation, fixation bacteria, and other factors cannot be predicted.
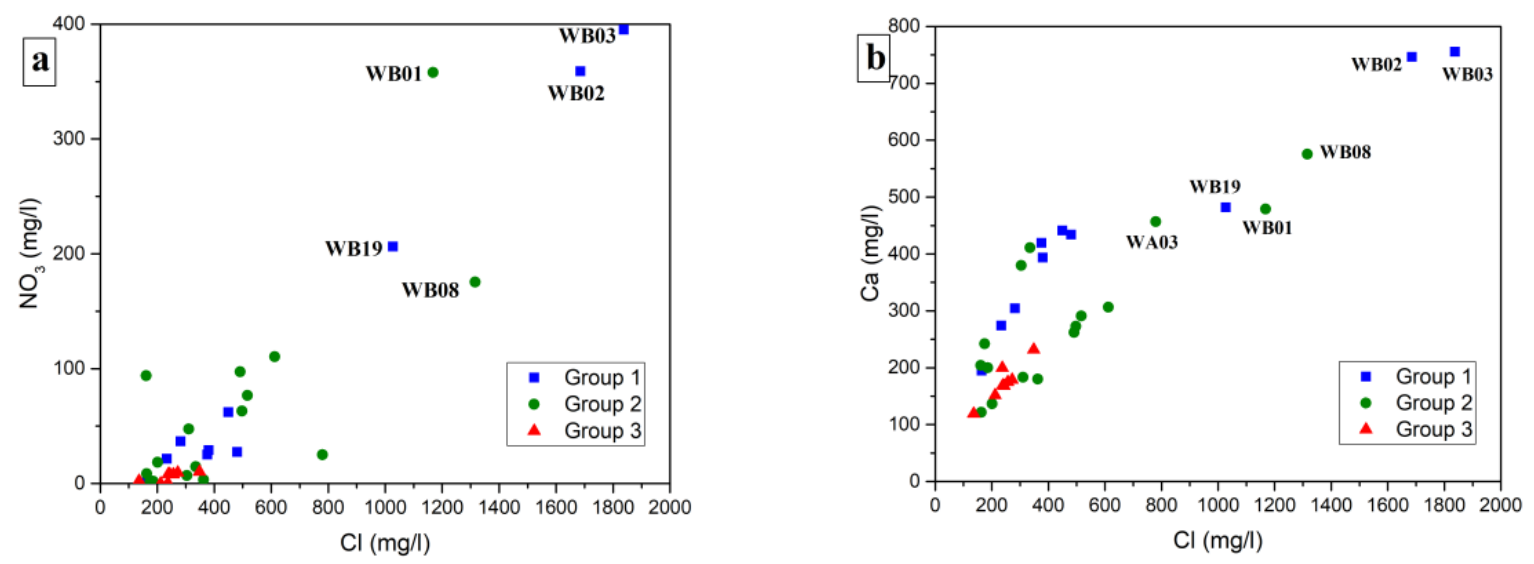

Figure 10. $\mathrm{Cl}^{-}$versus $\mathrm{NO}_{3}^{-}(\mathbf{a})$ and $\mathrm{Cl}^{-}$versus $\mathrm{Ca}^{2+}(\mathbf{b})$ concentrations of 34 groundwater samples from the Al Kharj area. 


\subsubsection{Nitrogen from Animal and Human Waste (Manures)}

The dominant nitrogen compound in animal and human wastes is urea. The enzyme urease hydrolyzes the urea to ammonium and then to nitrate in the vadose zone, where it can percolate down to the water table [3]. The hydrolysis of urea results in a momentary increase in $\mathrm{pH}$ that helps the transformation to $\mathrm{NH}_{3}$ gas, which is released to the atmosphere.

The studied water samples from the Wasia aquifer have no or undetectable concentrations of ammonia. Depending on the availability of oxygen, $\mathrm{NH}_{4}{ }^{+}$may be oxidized and detected only as $\mathrm{NO}_{3}{ }^{-}$. Therefore, $\mathrm{N}$ input from animal or human waste may not be detected as ammonium. The presence of iron in the groundwater also helps nitrifying bacteria in ammonia oxidization to nitrite and then to nitrate $[40,41]$. Besides elevated nitrate concentrations, groundwater affected by manures usually has high $\mathrm{Cl}^{-}$and $\mathrm{K}^{+}$amounts [3]. While $\mathrm{K}^{+}$is basically low $(<11.5 \mathrm{mg} / \mathrm{L})$ in the studied Wasia aquifer, a strong correlation between $\mathrm{Cl}^{-}$and $\mathrm{NO}_{3}{ }^{-}$was found in the samples (Figure 10). The effect of manure on the hydrochemical composition of the Wasia aquifer seems to be negligible or minor, as $\mathrm{NH}_{4}, \mathrm{PO}_{4}$, and $\mathrm{NO}_{2}$ are absent in those samples.

\subsubsection{Nitrogen from Rocks}

Elevated nitrogen in rocks has been measured in igneous, metamorphic, and especially in sedimentary deposits and metasediments [10]. Nitrogen is easily weathered under surface conditions, and it can be discharged as a solution in the saturated zone due to the high solubility of nitrate salts [3]. The Wasia Group, which represents the main aquifer in the Al Kharj area, generally consists of sandstone, conglomerate, and shale layers $[23,25,42]$. As there is no mention of nitrate salts present in the Wasia Group and the underlying and overlying rocks, it is unlikely that such salts are source for nitrate in the studied groundwater samples.

\subsubsection{Soil Nitrogen}

Nitrogen may exist naturally in the soil, as some symbiotic soil bacteria fix atmospheric nitrogen. Nitrogen also occurs in plants like the legume family [43]. These processes take part in the nitrogen cycle. This accumulation of nitrate in the unsaturated zone can form a large nitrate pool which may infiltrate to the saturation zone during recharge periods. Although the isotopic composition of one of the studied samples (WB06) lies within the soil nitrogen area (Figure 8), it is unlikely that soil nitrogen has contributed to the nitrogen content in the studied samples. This sample may have been affected by manure and wastewater nitrogen.

\subsection{Estimating N Fluxes}

To evaluate whether the rates of nitrate percolation to the aquifer and recharge amount are sufficient to explain the nitrate concentration in the studied samples, the estimated nitrate fluxes were compared to the calculated aquifer exchange time. Considering an average thickness of $100 \mathrm{~m}, 30 \%$ of effective porosity, and a recharge rate of 5 to $10 \mathrm{~mm} /$ year for the aquifer in the study area [16], a direct water budget calculation resulted in a required 3000 to 6000 years for the complete exchange of water assuming steady-state conditions. The average nitrate concentration measured in the groundwater of this study $(68.2 \mathrm{mg} / \mathrm{L})$ would give around $20,000 \mathrm{~kg} / \mathrm{ha}$ of overall nitrate for a $100 \mathrm{~m}$ aquifer thickness. Based on the time required to exchange the geochemical composition of the aquifer, an average 3.34 to $6.67 \mathrm{~kg} /$ (ha) per year of nitrate flux would be required to match the overall nitrate in the aquifer. This calculated amount of nitrate flux cannot be explained by one single source. Therefore, a combination of synthetic fertilizers and atmospheric deposition is most likely to be responsible for the detected nitrate concentrations. This interpretation coincides with a regional groundwater survey in Saudi Arabia, where 213 out of 1060 wells were encountered to exceed the maximum limit of $50 \mathrm{mg} / \mathrm{L}$ for nitrate in drinking water [44]. Most affected wells were reported in areas, listed in descending order, with agricultural-residential, agricultural, housing-desert, housing, desert, and industrial land use. 


\subsection{Wasia Aquifer: Mixing Model and Nitrate Provenance}

Wells with the lowest salinity concentrations between 1100 and $2000 \mathrm{mg} / \mathrm{L}$ in the Al Kharj area are generally coupled to low nitrate concentration with values below $20 \mathrm{mg} / \mathrm{L}$ (Figure 10a). Therefore, low saline groundwater samples from $\mathrm{Ca}-\mathrm{SO}_{4}-\mathrm{Cl}$ (Group 1) and $\mathrm{Ca}-\mathrm{SO}_{4}$ (Group 2) water types, plus all $\mathrm{Ca}-\mathrm{Na}-\mathrm{SO}_{4}-\mathrm{Cl}$ type samples (Group 3) are considered to represent pristine fluids from the Wasia aquifer without anthropogenic input or influx from the surface (Figure 10a,b). The salinity range $(1100-2000 \mathrm{mg} / \mathrm{L})$ for Wasia groundwater in the Al Kharj area is even lower than the reported TDS concentration of $2500 \mathrm{mg} / \mathrm{L}$ for the Wasia-Biyadh aquifer in the region west of Khurais [45]. In contrast, elevated nitrate, chloride, TDS, and ${ }^{18} \mathrm{O}-\mathrm{NO}_{3}$ values (up to $395 \mathrm{mg} / \mathrm{L}$ ) and depleted ${ }^{15} \mathrm{~N}-\mathrm{NO}_{3}$ ratios of water samples from two local spots in the northern (WB08, WB09) and eastern (WB01, WB02, WB03, WB19) part of the study area imply the mixing of pristine Wasia groundwater with surface water influx. The positive correlation between $\mathrm{Cl}, \mathrm{Ca}$, and $\mathrm{NO}_{3}$ suggests the presence of two sources (Figure 11). Arid climatic conditions triggered the extreme evaporation of irrigation water on crop areas, with the subsequent infiltration of fertilizer- and salt-enriched irrigation water into the Wasia aquifer system.
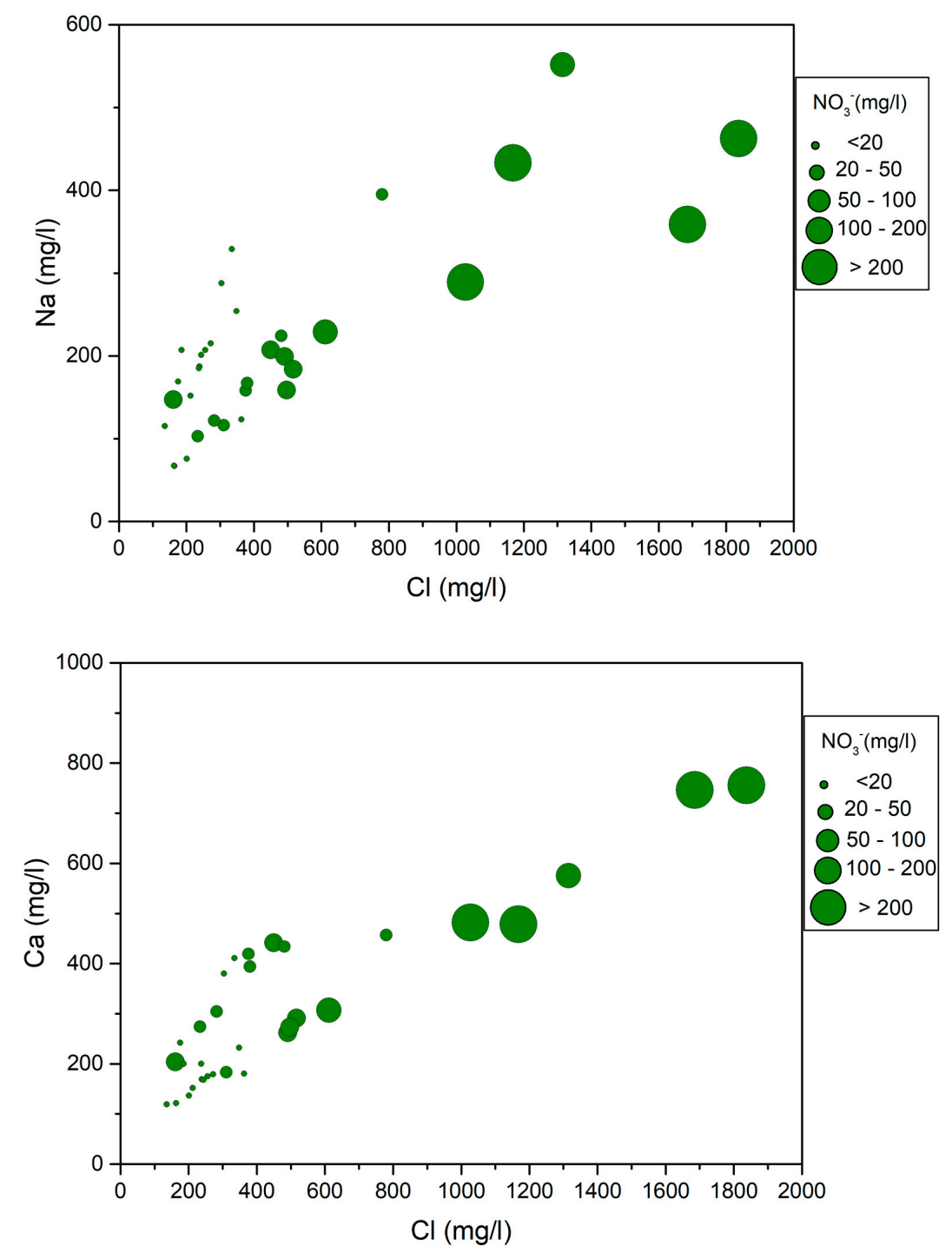

Figure 11. Positive compositional correlation between $\mathrm{NO}_{3}{ }^{2-}$ and $\mathrm{Cl}^{-}, \mathrm{Ca}^{2+}$, and $\mathrm{Na}^{-}$in Wasia groundwater in the Al Kharj area. 
The heterogeneous composition of 20 Wasia groundwater samples from 2015 with a minimum and maximum concentration of 1433 to $5619 \mathrm{mg} / \mathrm{L}$ for TDS and 24.5 to $378 \mathrm{mg} / \mathrm{L}_{\text {for }} \mathrm{NO}_{3}$ [14] is the same range as that of the present sampling. The geochemical similarity reflects the continuous impact of agricultural activities on the shallow groundwater system in the Al Kharj region

The comparison of specific land use zones in the study area with anomalies in nitrate concentration in groundwater was performed to validate the potential local influx of fertilizer-enriched irrigation water in crop areas. In theory, groundwater in crop areas should be a major target for fertilizer influx. The satellite map in Figure 12 illustrates areas with dominant housing, dairy, poultry, and agricultural farms as dominant land use types. The wells WB02, WB03, and WB09 with the highest nitrate concentrations (206-395 mg/L) are located within an agricultural zone in the eastern part of the study area, where dark-grey to greenish circles reflect the active use of radial irrigation sprinklers. In contrast, water samples from the wells WB08 and WB09 in the northern zone have also elevated nitrate concentrations (111-175 mg/L), but no current residential or agriculture land use can be identified in their neighborhood on satellite images. Generally, none of the sampled supply wells was located within housing, dairy or poultry areas, but some specific wells show slightly elevated nitrate concentrations close to active rural, industrial or agricultural zones. Samples from the wells WB13, WB14, and WB17 are located east of a local housing area (Figure 12). The eastward-directed groundwater flow could explain the presence of slightly elevated nitrate concentrations (27.4-36.8 mg/L) for the mentioned wells. Most of the groundwater wells are located outside the populated and farmed zones and are generally not affected by anthropogenic nitrate, as reflected by concentrations between $<1 \mathrm{mg} / \mathrm{L}$ and $15 \mathrm{mg} / \mathrm{L}$.

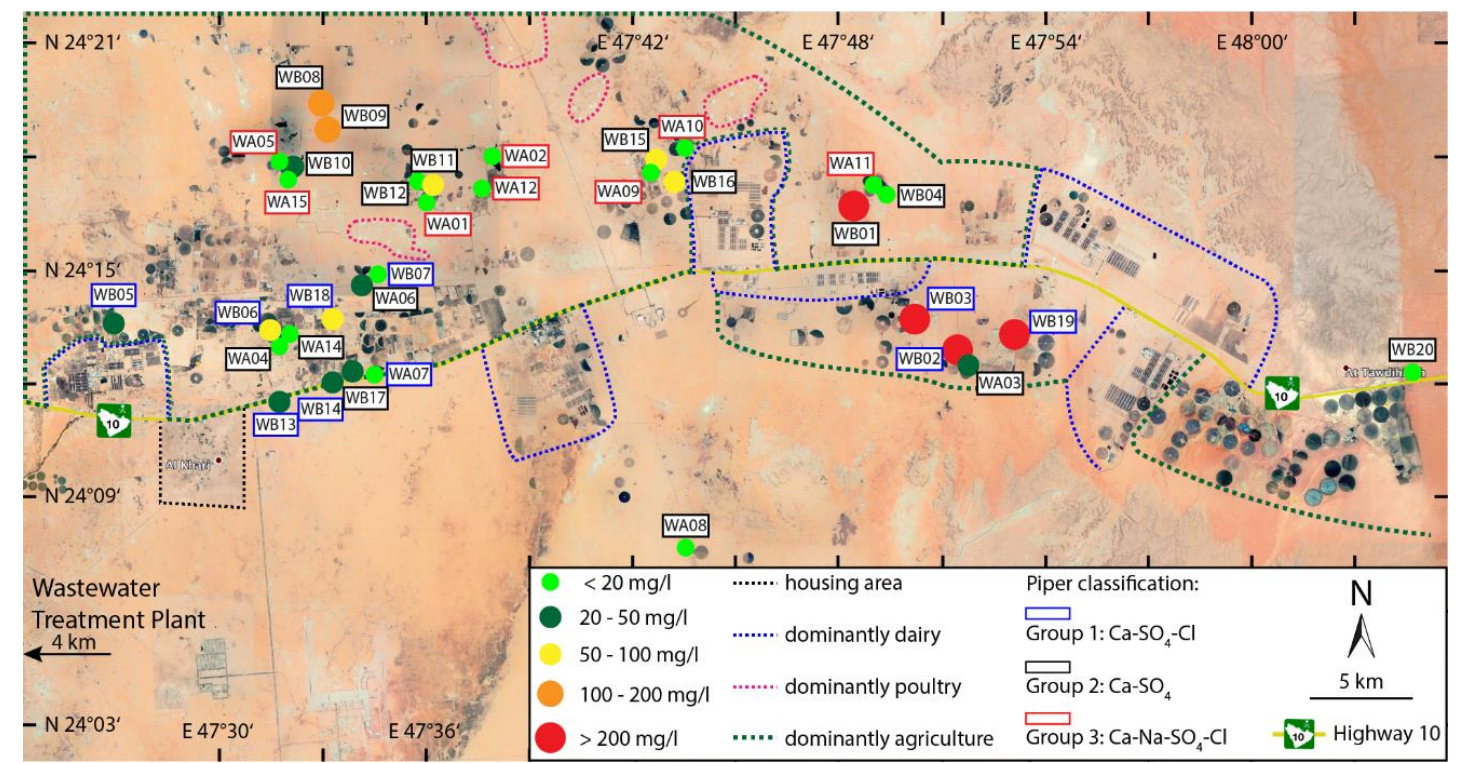

Figure 12. Google Earth map of measured nitrate concentrations of Wasia-Biyadh groundwater in project wells, well numbers, and areas of dominant land use in the study area.

Well WB20 at the most eastern edge of an extensive irrigation field in the most eastern part of the study area is not affected by the proximity distance to an extensive irrigation area, as reflected by minor nitrate concentration of $18.4 \mathrm{mg} / \mathrm{L}$. Potential reasons could be the diversified application of fertilizers for different agricultural products. In the present case, large radial irrigation areas for the watering of alfalfa are probably less demanding for the use of fertilizer, therefore infiltrating irrigation water is less contaminated with nitrate.

\section{Conclusions}

Source-related signatures of ${ }^{15} \mathrm{~N}-\mathrm{NO}_{3}$ and ${ }^{18} \mathrm{O}-\mathrm{NO}_{3}$ were measured in groundwater samples from the Cretaceous Wasia aquifer in central Saudi Arabia. Two local spots in the eastern and northern 
parts of the study area are characterized by atmospheric and fertilizers-derived nitrate as inferred from ${ }^{15} \mathrm{~N}-\mathrm{NO}_{3}$ and ${ }^{18} \mathrm{O}-\mathrm{NO}_{3}$ signatures, and distinguished by adjacent areas by elevated salinity, $\mathrm{B}, \mathrm{NO}_{3}$, and $\delta^{18} \mathrm{O}_{\mathrm{NO} 3}$ values. The high salinity of 4940 to $7330 \mathrm{mg} / \mathrm{L}$ could be an influx of evaporated irrigation water, connate water or a mixture of both sources.

The lowest saline groundwater samples (TDS $=1400-2000 \mathrm{mg} / \mathrm{L}$ ) from the peripheral and southwestern zone of the study area were representative for pristine groundwater from the Wasia aquifer with nitrate concentrations below $20 \mathrm{mg} / \mathrm{L}$, low ${ }^{18} \mathrm{O}-\mathrm{NO}_{3}$ ratios $(8.7-20.6 \%$ ), but had the highest ${ }^{15} \mathrm{~N}-\mathrm{NO}_{3}$ ratios (up to $10.8 \%$ ). There was no evidence for the influx of animal or human waste from adjacent dairy farms, poultry farms and housing settlements. Higher saline samples ( 4940 to $7330 \mathrm{mg} / \mathrm{L}$ ) from local wells in the eastern and northern part of the $\mathrm{Al}$ Kharj region were enriched in $\mathrm{NO}_{3}$ (up to $395 \mathrm{mg} / \mathrm{L}$ ), and their negative trend with enrichment in ${ }^{18} \mathrm{O}-\mathrm{NO}_{3}$ and depletion in ${ }^{15} \mathrm{~N}-\mathrm{NO}_{3}$ reflects the nitrification of Wasia groundwater by fertilizer.

The low tritium $\left({ }^{3} \mathrm{H}\right)$ concentration of the Wasia groundwater, however, indicates the absence of recent recharge or the mixture of recent influx with fossil waters. This is corroborated by the calculated percolation time of between 3000 years and 6000 years needed to effectively exchange the groundwater on a local scale. Tritium concentrations below the detection limit of $0.8 \mathrm{TU}$ could be correlated to a late Pleistocene recharge event of the Wasia aquifer as observed for the underlying Paleozoic and Triassic Jilh aquifers using the radiocarbon dating method [30,31]. The samples "WB03" and "WB08" with the highest tritium and nitrate concentrations may indicate the influx of recent surface water. It can be concluded that natural sources, such as atmospheric deposition as well as anthropogenic sources of $\mathrm{N}$-fertilizer, contribute to the nitrogen budget and to spatial heterogeneities of the Wasia aquifer.

Author Contributions: A.K. wrote, conducted, and analyzed experimental data of this research. A.A.-S. was responsible for designing and analyzing the work. P.B. provided constructive comments, reviews, and edits for this manuscript. M.M. and B.T. contributed to the discussion of the results and to the analysis. M.K. provided constructive comments and edits. All authors have read and agreed to the published version of the manuscript.

Funding: This research was funded by the College of Petroleum Engineering and Geosciences (CPG), King Fahd University of Petroleum and Minerals (KFUPM) under the startup fund number (SF18061).

Acknowledgments: The authors would like to acknowledge the College of Petroleum Engineering and Geosciences (CPG), King Fahd University of Petroleum and Minerals (KFUPM), for the funding and support, and providing facilities for the present study. We greatly appreciate the support of Abdullatif Al-Shuhail. We thank the Exploration Geospatial and Data Management Solutions Division at Saudi Aramco for adjusting the boundaries and coordinates of provided maps.

Conflicts of Interest: The authors declare no conflict of interest.

\section{References}

1. Widory, D.; Kloppmann, W.; Chery, L.; Bonnin, J.; Rochdi, H.; Guinamant, J.L. Nitrate in groundwater: An isotopic multi-tracer approach. J. Contam. Hydrol. 2004, 72, 165-188. [CrossRef] [PubMed]

2. Postma, D.; Boesen, C.; Kristiansen, H.; Larsen, F. Nitrate reduction in an unconfined sandy aquifer: Water chemistry, reduction processes, and geochemical modeling. Water Resour. Res. 1991, 27, 2027-2045. [CrossRef]

3. Stadler, S.; Osenbrück, K.; Knöller, K.; Suckow, A.; Sültenfuß, J.; Oster, H.; Himmelsbach, T.; Hötzl, H. Understanding the origin and fate of nitrate in groundwater of semi-arid environments. J. Arid Environ. 2008, 72, 1830-1842. [CrossRef]

4. Hem, J.D. Study and Interpretation the Chemical of Natural of Characteristics Water, 3rd ed.; USGS: Alexandria, Egypt, 1985; Volume 2254, ISBN 2254.

5. Stadler, S. Investigation of Natural Processes Leading to Nitrate Enrichment in Aquifers of Semi-Arid Regions; University of Karlsruhe: Karlsruhe, Germany, 2006.

6. Kendall, C.; Elliott, E.M.; Wankel, S.D. Tracing anthropogenic inputs of nitrogen to ecosystems. In Stable Isotopes in Ecology and Environmental Science, 2nd ed.; Michener, R., Lajtha, K., Eds.; Blackwell Publishing Ltd.: Oxfordshire, UK, 2007; Chapter 12; pp. 375-449. 
7. Addiscott, T.M.; Whitmore, A.P.; Powlson, D.S. Farming, Fertilizers and the Nitrate Problem; CAB International CABI: Wallingford, UK, 1991; ISBN 0851986587.

8. Wakida, F.T.; Lerner, D.N. Non-agricultural sources of groundwater nitrate: A review and case study. Water Res. 2005, 39, 3-16. [CrossRef]

9. Canter, L.W. Nitrates in Groundwater; CRC Press Inc.: Boca Raton, FL, USA, 1997.

10. Holloway, J.M.; Dahlgren, R.A. Nitrogen in rock: Occurrences and biogeochemical implications. Glob. Biogeochem. Cycles 2002, 16, 1118. [CrossRef]

11. Alfaifi, H.J.; Abdelfatah, M.S.; Abdelrahman, K.; Zaidi, F.K.; Ibrahim, E.; Alarifi, N.S. Groundwater Management Scenarios for the Biyadh-Wasia Aquifer Systems in the Eastern Part of Riyadh Region, Saudi Arabia. J. Geol. Soc. India 2017, 89, 669-674. [CrossRef]

12. Ministry of Agriculture and Water (MAW). Water Atlas of Saudi Arabia. In Ministry of Agriculture and Water in Cooperation with the Saudi Arabian-United Sates Joint Commission on Economic Cooperation; MAW: Riyadh, Saudi Arabia, 1984.

13. Al-Omran, A.M.; Aly, A.A.; Al-wabel, M.I. Hydrochemical characterization of groundwater under agricultural land in arid environment: A case study of Al Kharj, Saudi Arabia. Arab. J. Geosci. 2016. [CrossRef]

14. Zaidi, F.K.; Mogren, S.; Mukhopadhyay, M.; Ibrahim, E. Evaluation of groundwater chemistry and its impact on drinking and irrigation water quality in the eastern part of the Central Arabian graben and trough system, Saudi Arabia. J. Afr. Earth Sci. 2016, 120, 208-219. [CrossRef]

15. Alharbi, T.G.; Zaidi, F.K. Hydrochemical classification and multivariate statistical analysis of groundwater from Wadi Sahba area in central Saudi Arabia. Arab. J. Geosci. 2018, 11, 643. [CrossRef]

16. GTZ/DCO. Detailed Water Resources Studies of Wasia-Biyadh and Aruma Aquifers-Groundwater Model and Water Management; Gesellschaft für Technische Zusammenarbeit, Dornier Consulting, Ministry of Water and Electricity: Riyadh, Saudi Arabia, 2013.

17. GTZ/DCO. Detailed Water Resources Studies of Wasia-Biyadh and Aruma Aquifers-Phase I Completion Report; Gesellschaft fur Technische Zusammenarbeit, Dornier Consulting, Ministry of Water and Electricity: Riyadh, Saudi Arabia, 2009.

18. Mayer, B.; Boyer, E.W.; Goodale, C.; Jaworski, N.A.; Van Breemen, N.; Howarth, R.W.; Seitzinger, S.; Billen, G.; Lajtha, K.; Nadelhoffer, K. Sources of nitrate in rivers draining sixteen watersheds in the northeastern US: Isotopic constraints. Biogeochemistry 2002, 57, 171-197. [CrossRef]

19. Wells, E.R.; Krothe, N.C. Seasonal fluctuation in $\delta 15 \mathrm{~N}$ of groundwater nitrate in a mantled karst aquifer due to macropore transport of fertilizer-derived nitrate. J. Hydrol. 1989, 112, 191-201. [CrossRef]

20. Clark, I.D.; Fritz, P. Environmental Isotopes in Hydrogeology; CRC press: Boca Raton, FL, USA, 1997.

21. Fetter, C.W. Applied Hydrogeology, 4th ed.; Pearson Education, Inc.: Harlow, UK, 2014; ISBN 9781292022901.

22. Almazroui, M. Calibration of TRMM rainfall climatology over Saudi Arabia during 1998-2009. Atmos. Res. 2011, 99, 400-414. [CrossRef]

23. Powers, R.W.; Ramirez, L.F.; Redmond, C.D.; Elberg, E.L.J. Geology of the Arabian Peninsula Sedimentary Geology of Saudi Arabia. U.S. Geol. Surv. Prof. Pap. 1966, 560, 154.

24. Sharief, F.A.; Magara, K.; Abdulla, H.M. Depositional system and reservoir potential of the Middle Cretaceous Wasia Formation in central-eastern Arabia. Mar. Pet. Geol. 1989, 6, 303-315. [CrossRef]

25. Keller, M.; Bohnsack, D.; Koch, R.; Hinderer, M.; Hornung, J.; Al-Ajmi, H.; Abu Amarah, B.A. Outcrop Analog Studies of the Wasia-Biyadh and Aruma Aquifers in the Kingdom of Saudi Arabia. In Siliciclastic Reservoirs of the Arabian Plate; Al Anzi, H.R., Rahmani, R.A., Steel, R.J., Soliman, O.M., Eds.; AAPG Memoir: Tulsa, OK, USA, 2019; Volume 116, pp. 317-382.

26. BRGM. Hydrogeological Investigations of the Al Wasia Aquifer in the Eastern Province of Saudi Arabia; Ministry of Agriculture and Water, Water Resources Development Department: Riyadh, Saudi Arabia, 1976; p. 109.

27. Bazuhair, A.S.A. Optimum Aquifer Yield of Four Aquifers in AI-Kharj Area, Saudi Arabia. Earth Sci. 1989, 2, 12. [CrossRef]

28. Edgell, H.S. Aquifers of Saudi Arabia and their geological framework. Arab. J. Sci. Eng. 1997, $22,3-31$.

29. ARAMCO. A Study of the Wasia Aquifer in Eastern Saudi Arabia; Aramco: Riyadh, Saudi Arabia, 1960; p. 128.

30. Birkle, P. Geochemical fingerprinting of hydraulic fracturing fluids from Qusaiba Hot Shale and formation water from Paleozoic petroleum systems, Saudi Arabia. Geofluids 2016, 16, 565-584. [CrossRef] 
31. GTZ/DCO. Detailed Water Resources Studies of Wajid and Overlying Aquifers_Environmental Isotopes; Gesellschaft für Technische Zusammenarbeit, Dornier Consulting, Ministry of Water and Electricity: Riyadh, Saudi Arabia, 2009.

32. Mcllvin, M.R.; Altabet, M.A. Chemical conversion of nitrate and nitrite to nitrous oxide for nitrogen and oxygen isotopic analysis in freshwater and seawater. Anal. Chem. 2005, 77, 5589-5595. [CrossRef]

33. WHO (World Health Organization). Guidelines for drinking-water quality. WHO Chron. 2011, 4, 104-108.

34. Michelsen, N.; Reshid, M.; Siebert, C.; Schulz, S.; Knöller, K.; Weise, S.M.; Rausch, R.; Al-Saud, M.; Schüth, C. Isotopic and chemical composition of precipitation in Riyadh, Saudi Arabia. Chem. Geol. 2015, 413, 51-62. [CrossRef]

35. Kendall, C.; McDonnell, J.J. Isotope Tracers in Catchment Hydrology; Elsevier: Amsterdam, The Netherlands, 1998; p. 839.

36. Vengosh, A.; Heumann, K.G.; Juraske, S.; Kasher, R. Boron isotope application for tracing sources of contamination in groundwater. Environ. Sci. Technol. 1994, 28, 1968-1974. [CrossRef]

37. Helvaci, C. Borates. In Encyclopedia of Geology; Selley, R.C., Cocks, L.R.M., Plimer, I.R., Eds.; Elsevier: Amsterdam, The Netherlands, 2005; Volume 3, pp. 510-522.

38. WHO. Guidelines for Drinking-Water Quality, 4th ed.; Incorporating the First Addendum; WHO: Geneva, Switzerland, 2017; p. 540. ISBN 978-92-4-154995-0.

39. Alabdula'aly, A.I.; Khan, M.A. Chemistry of rain water in Riyadh, Saudi Arabia. Arch. Environ. Contam. Toxicol. 2000, 39, 66-73. [CrossRef] [PubMed]

40. Meiklejohn, B.Y.J. Iron and the Nitrifying Bacteria. Microbiology 1953, 8, 58-65. [CrossRef] [PubMed]

41. Qian, G.; Hu, X.; Li, L.; Ye, L.; Lv, W. Effect of iron ions and electric field on nitrification process in the periodic reversal bioelectrocoagulation system. Bioresour. Technol. 2017, 244, 382-390. [CrossRef] [PubMed]

42. Le Nindre, Y.M.; Vaslet, D.; Maddah, S.S.; Al-Husseini, M.I. Stratigraphy of the Valanginian? To early Paleocene succession in central Saudi Arabia outcrops: Implications for regional Arabian sequence stratigraphy. GeoArabia 2008, 13, 51-86.

43. Keeney, D.; Olson, R.A. Sources of Nitrate to Ground Water; Taylor \& Francis: Abingdon-on-Thames, UK; London, UK, 1986; Volume 16, ISBN 1064338860.

44. Alabdula'aly, A.; Al-Rehaili, A.M.; Al-Zarah, A.I.; Khan, M.A. Assessment of nitrate concentration in groundwater in Saudi Arabia. Environ. Monit. Assess. 2010, 161, 1-9. [CrossRef] [PubMed]

45. Al-Mutaz, I.S. Water resources development in Riyadh, Saudi Arabia. Desalination 1987, 64, $193-202$. [CrossRef] 